\title{
ErbB Expression: The Mouse Inner Ear and Maturation of the Mitogenic Response to Heregulin
}

\author{
Clifford R. Hume, Mette Kirkegaard, and Elizabeth C. Oesterle \\ Department of Otolaryngology-Head and Neck Surgery, Virginia Merrill Bloedel Hearing Research Center, \\ University of Washington, Seattle, WA 98195, USA
}

Received: 15 March 2002; Accepted: 26 March 2003; Online publication: 6 June 2003

\section{ABSTRACT}

In humans, hair cell loss often leads to hearing and balance impairments. Hair cell replacement is vigorous and spontaneous in avians and nonmammalian vertebrates. In mammals, in contrast, it occurs at a very low rate, or not at all, presumably because of a very low level of supporting cell proliferation following injury. Heregulin (HRG), a member of the epidermal growth factor (EGF) family of growth factors, is reported to be a potent mitogen for neonatal rat vestibular sensory epithelium, but its effects in adults are unknown. We report here that HRG- $\alpha$ stimulates cell proliferation in organotypic cultures of neonatal, but not adult, mouse utricular sensory epithelia. Our findings support the idea that the proliferative capabilities of the adult mammalian vestibular sensory epithelia differ significantly from that seen in neonatal animals. Immunohistochemistry reveals that HRG-binding receptors (erbBs 2-4) and erbB1 are widely expressed in vestibular and auditory sensory epithelia in neonatal and adult mouse inner ear. The distribution of erbBs in the neonatal and adult mouse ear is consistent with the EGF receptor/ligand family regulating diverse cellular processes in the inner ear, including cell proliferation and differentiation.

Keywords: auditory, vestibular, hair cell regeneration, growth factor, cochlea, proliferation

Present address (Mette Kirkegaard): Department of Zoophysiology, Bld. 131, Universitetsparken, University of Aarhus, Denmark Correspondence to: Elizabeth C. Oesterle - Virginia Merrill Bloedel Hearing Research Center - Box 357923 - University of Washington • Seattle, WA 98195-7923. Telephone: (206) 616-4108; fax: (206) 6161828; email: oesterle@u.washington.edu

\section{INTRODUCTION}

The vertebrate inner ear contains multiple types of sensory hair cells that are responsible for the detection of sound and motion. In birds, if the sensory epithelium is damaged, supporting cell precursors are stimulated to proliferate and differentiate into new hair cells (Corwin and Cotanche 1988; Ryals and Rubel 1988; Weisleder and Rubel 1993). As these new hair cells are reinnervated, this efficient and highly ordered process results in the restoration of auditory and vestibular function (reviewed in Cotanche et al. 1994; Carey et al. 1996; Stone et al. 1998; Cotanche 1999; Smolders 1999). In contrast to birds, mammals are unable to regenerate auditory hair cells and have a very limited ability to regenerate vestibular hair cells via a mitotic pathway if the sensory epithelium is damaged (Warchol et al. 1993; Lambert 1994; Rubel et al. 1995; Tanyeri et al. 1995; Li and Forge 1997; Zheng and Gao 1997; Kuntz and Oesterle 1998a; Forge et al. 1998).

Little is known about the signals that regulate the regeneration of hair cells. Despite the testing of extensive numbers of known growth factors by several groups, factors capable of stimulating proliferation in the mammalian auditory epithelium, the organ of Corti, have not yet been identified. Only a few factors show some promise of increasing proliferation and promoting new hair cell formation in the mammalian vestibular sensory epithelium (reviewed in Staecker and Van de Water 1998; Oesterle and Hume 1999). The most effective of these, epidermal growth factor (EGF) (Yamashita and Oesterle 1995; Zheng et al. 1997, 1999), transforming growth factor alpha (TGFa) (Lambert 1994; Yamashita and Oesterle 1995; Zheng et al. 1997, 1999; Kuntz and Oesterle 1998a; 
Oesterle et al. 2003), glial growth factor 2 (GGF2) (Montcouquiol and Corwin 2001), heregulin (HRG) (Zheng et al. 1999), and neu-differentiation factor (NDF) (Gu et al. 1998, 1999), are structurally related members of the EGF-ligand family. GGF2, HRG, and NDF are also members of the neuregulin family, a subfamily of the larger EGF-ligand family that consists of over 15 splice isoforms arising from a single gene, NRG1.

The most studied of these ligands in the inner ear to date, TGF- $\alpha$, has been shown to stimulate supporting cell proliferation in cultured utricular sensory epithelium from neonatal rats and adult mice (Lambert 1994; Yamashita and Oesterle 1995; Zheng et al. 1997, 1999). TGF- $\alpha$ 's mitogenic effects are potentiated by insulin (Yamashita and Oesterle 1995; Kuntz and Oesterle 1998a), and TGF- $\alpha$ plus insulin infusion into the adult rat ear stimulates the production of new supporting cells, and possibly new hair cells, in the utricular sensory epithelium in vivo (Kuntz and Oesterle 1998a; Oesterle et al. 2003). EGF, when used in combination with insulin, also stimulates supporting cell proliferation in an in vitro organotypic culture system from adult mice (Yamashita and Oesterle 1995) and in isolated sheets of neonatal utricular sensory epithelium (Zheng et al. 1997, 1999).

Several members of the neuregulin family, GGF2, NDF, and heregulin (HRG) $\beta$, are mitogenic for neonatal vestibular sensory epithelia (Gu et al. 1998, 1999; Zheng et al. 1999; Montcouquiol and Corwin 2001). In the adult, their effects are unknown (NDF, HRG) or incompletely characterized (GGF2, Gu et al. 1997). HRG- $\beta$ appears to be a potent mitogen for neonatal vestibular sensory epithelia; a tenfold increase in the numbers of sensory epithelial (SE) cells synthesizing DNA was reported in cultures supplemented with HRG- $\beta$ relative to that seen in control cultures (Zheng et al. 1999). Its effects need to be explored in adult tissues to determine its capabilities as a potential therapeutic agent for alleviating sensory-neural hearing loss or vestibular disorders in mammals, possibly in humans. The mitogenic effects of growth factors often vary developmentally in many tissues; hence, factors that are mitogenic for neonatal inner ear sensory epithelia may not necessarily have similar effects in adult tissues.

As summarized in Figure 1, signaling by members of the EGF family of ligands is mediated by four interacting transmembrane tyrosine kinase receptors: erbB1 (EGFR, HER), erbB2 (HER2, neu), erbB3 (HER3), and erbB4 (HER4) (for review, see Carraway and Cantley 1994; Lemke 1996; Burden and Yarden 1997; Riese and Stern 1998; Adlkofer and Lai 2000). The erbB receptors differ in both their ligand affinity and signaling activity. ErbB receptor family members, with the exception of erbB2, bind multiple ligands. Ligand binding induces receptor dimerization and activation of the intrinsic tyrosine kinase followed by activation of downstream signaling pathways. Receptor dimerization can take place between identical receptors (homodimers) or with any of the other erbB family members (heterodimers), depending on which receptors are expressed in a given cell (Riese et al. 1996a, b; Sliwkowski et al. 1994). ErbB2 does not have an identified ligand, but it is frequently activated as a result of receptor heterodimerization (Alroy and Yarden 1997; Sliwkowski et al. 1994). ErbB3 is an unusual receptor in that it does not possess any kinase activity, although it can recruit other receptors to form active heterodimers (Guy et al. 1994).

There are three functional groups of EGF-related ligands based on their ability to bind individual erbB receptors (Fig. 1) (reviewed in Riese and Stern 1998). One group of ligands (EGF, TGF- $\alpha$, and amphiregulin) binds to receptors containing erbB1 (EGFR). The second group, the neuregulins (NRGs1-4), including HRG, binds to receptors containing erbB3 or erbB4, and the third group [betacellulin (BC), heparin-binding EGF (HB-EGF), and epiregulin (EPR)] binds to receptors containing either erbB1 or erbB4.

We examined the mitogenic effects of HRG- $\alpha$ in organotypic cultures of normal, undamaged utricular macula taken from neonatal (P3-P5) and adult mice (4-6 weeks). HRG- $\alpha$ was found to stimulate DNA synthesis in neonatal, but not adult, utricular macula. Immunohistochemistry and immunofluorescence revealed that erbBs 1, 2, 3, and 4 are widely expressed in the neonatal vestibular sensory epithelia and organ of Corti. We also show that erbBs 1, 2, 3, and 4 are expressed in distinct, but overlapping, subsets of cells within the adult mouse ear. The distribution of erbBs in the neonatal and adult mouse ear is consistent with the EGF receptor/ligand family regulating diverse cellular processes in the inner ear, including cell proliferation, differentiation, survival, and motility. The limited proliferation of mammalian inner ear sensory epithelia in response to EGF family members does not appear to be due to the lack of erbB receptor expression.

\section{MATERIALS AND METHODS}

\section{Animals}

Animal care and sacrifice were conducted according to methods approved by the University of Washington Animal Care Committee. Adult (4-12 weeks old) mice (Swiss Webster) were sacrificed by cervical dislocation (for cultured tissue only) or by anesthesia with $\mathrm{CO}_{2}$ followed by cervical dislocation. Postnatal day (P) 1-5 mice were sacrificed by decapitation. 


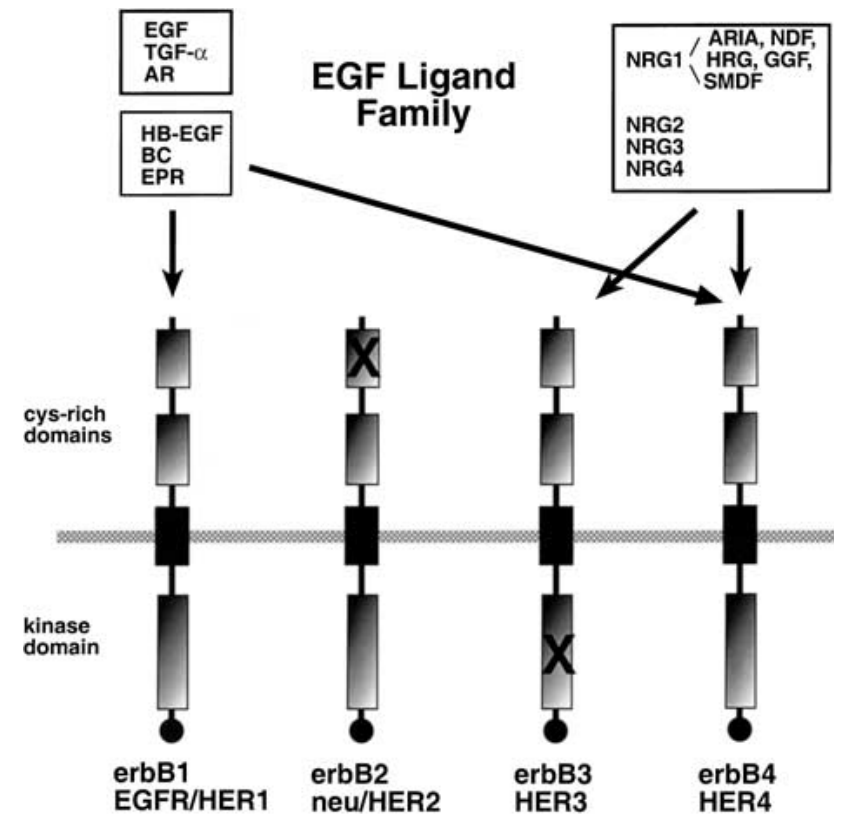

EGF Receptor Family

FIG. 1. Schematic diagram of the erbB receptor protein tyrosine kinase subfamily and some of ligands. The extracellular region is characterized by two large cysteine-rich (Cys-rich) regions. The erbB receptors can be activated as homodimers or as heterodimers and nearly all combinations are believed possible. ErbB2 has no known ligand, and it is only activated by heterodimerization with the other erbBs. ErbB3 exhibits no catalytic activity but can be phosphorylated by its heterodimerization partner. Ligands binding to the erbBs are listed in the boxes. They can be subdivided into three functional classes. The first group of ligands binds to erbB1 (EGFR) and includes epidermal growth factor (EGF) itself, transforming growth factor alpha (TGF- $\alpha$ ), and amphiregulin (AR). The second group of ligands binds and activates erbB1 and erbB4 and includes heparin-binding EGF-like growth factor (HB-EGF), betacellulin (BC), and epiregulin (EPR). The third group consists of another family of EGF-related proteins, the neuregulins (NRGS), which bind erbB3 and erbB4. The NRGS are EGFlike molecules arise by alternative splicing from a single gene (NRG-1). Recently, three other neuregulin-like genes have been described: NRG-2 (Carraway et al. 1997; Chang et al. 1997), NRG-3 (Zhang et al. 1997), and NRG-4 (Harari et al. 1999). The NRG-1/neuregulin family includes heregulin (HRG), acetylcholine receptor inducing activity (ARIA), neu-differentiation factor (NDF), glial growth factor (GGF), and sensory and motor neuron-derived factor (SMDF). The HRG members contain two isoforms differing in their EGF-like domain (isoforms $\alpha, \beta$ ). The $\alpha$ and $\beta$ isoforms bind differently to receptors and elicit different biological responses (Marikovsky et al. 1995; Back and Kim 1998; Crovello et al. 1998). Solid arrows indicate direct binding of a ligand family to a receptor.

\section{Growth factors}

Recombinant human heregulin- $\alpha$ (EGF domain; amino acid residues 177-241; Catalog No. 296-HR) was purchased from R \& D Systems (Minneapolis, MN).

\section{Cultures}

Previously described culture techniques (Yamashita and Oesterle 1995) were employed. After decapitation, heads were immersed in ice-cold $70 \%$ alcohol and transferred into sterile cold Hanks Balanced Salt Solution (HBSS). The utricles were isolated and placed free-floating into wells of 24-well tissue culture plates (one utricle per well) filled with $2 \mathrm{ml}$ of Basal Medium Eagle (BME) (GIBCO, Rockville, MD) supplemented with Earle's Balanced Salt Solution (EBSS) (GIBCO; BME:EBSS $=2: 1), 0.5 \%$ glucose (Sigma, St. Louis, $\mathrm{MO}$ ), and $0.1 \%$ fetal bovine serum (Atlanta Biologicals Inc., Norcross, GA). To test the efficacy of the HRG- $\alpha$ isoform on proliferation, $5,25,50$, and $100 \mathrm{ng} / \mathrm{ml}$ of HRG- $\alpha$ was added to the experimental cultures at the beginning of the culture period. Growth factor was not added to the control cultures, which were otherwise cultured identically to the experimental cultures. Fivebromo-2'-deoxyuridine (BrdU; Sigma) was added to all cultures at $1 \mu \mathrm{M}$ at the start of the culture period to identify cells that passed through $\mathrm{S}$ phase. Utricles were cultured for 6 days at $37^{\circ} \mathrm{C}$ in $5 \% \mathrm{CO}_{2} / 95 \%$ air, immersion fixed in $4 \%$ paraformaldehyde in $0.1 \mathrm{M}$ phosphate buffer ( $\mathrm{pH} \mathrm{7.4)} \mathrm{for} 20 \mathrm{~min}$, and processed for immunofluorescence for BrdU and a hair cell-specific marker as described below. Three to four experimental runs were conducted ( 3 for adults, 4 for neonatals), and four to ten organs per experimental paradigm were studied.

\section{Paraffin and cryostat sections}

Adults. The temporal bones from adult mice were dissected free in ice-cold HBSS. After removal of the bulla, the stapes was gently lifted from the oval window, cochleostomies were made at the apical and basilar turns, and the semicircular canals were transected. Icecold, fresh $4 \%$ paraformaldehyde in $0.1 \mathrm{M}$ phosphate buffer, $\mathrm{pH} 7.4$, was then perfused slowly through the cochlea, and the temporal bones were transferred to fixative overnight at $4^{\circ} \mathrm{C}$. Temporal bones were decalcified at room temperature in 0.4 M EDTA (pH 8.0) $1 \%$ paraformaldehyde for up to 5 days with daily solution changes. Mouse retinae, used as positive controls, were prepared in an identical fashion. The tissue was prepared in one of three ways for immunohistochemical processing: (1) half-temporal-bone preparations, (2) paraffin sections, or (3) cryostat sections. Specifically, to obtain half-temporal-bone preparations, decalcified temporal bones were bisected along the modiolar axis using an ultrathin razor blade and processed for immunohistochemistry as described below. To obtain paraffin sections of the inner ear, decalcified temporal bones were dehydrated with a graded ethanol series, cleared in methyl salicylate, and infiltrated with Paraplast Plus at $60^{\circ} \mathrm{C}$. The entire inner ear was sectioned transversely at 3-6 $\mu \mathrm{m}$ and sections were mounted onto glass slides. To obtain cryostat sections of the inner ear, decalcified temporal bones were immersed in $30 \%$ 

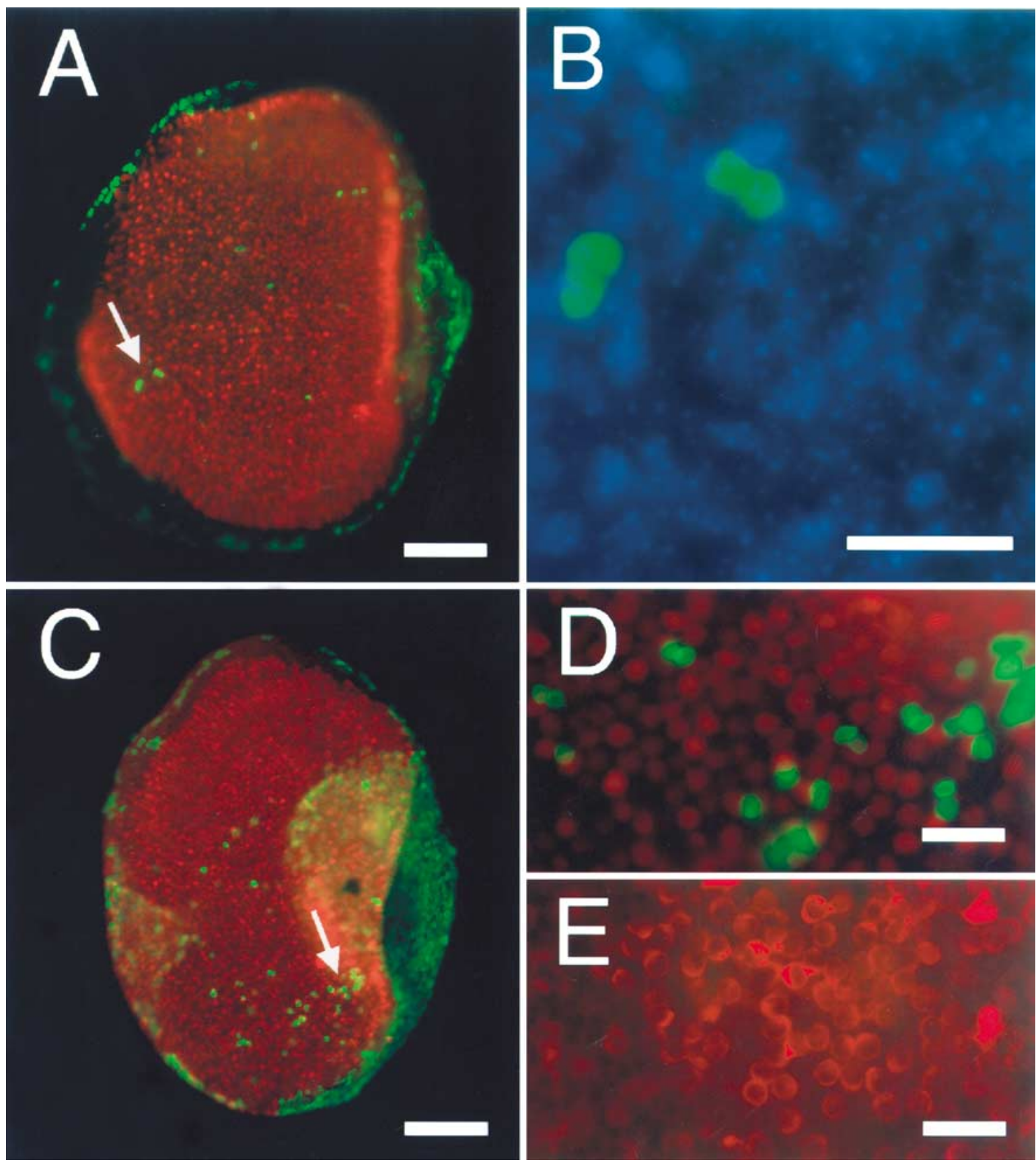

FIG. 2. Mouse utricular maculae grown for 6 days in culture medium supplemented with $\mathrm{BrdU}$ in the absence $(\mathbf{A}, \mathbf{B})$ or presence (C-E) of HRG- $\alpha$. Utricles were triple labeled for BrdU (green), a hair cell-specific marker (red) (calretinin for neonatal tissue, myosin VI for adult tissue), and the nuclear label bisbenzimide (blue). A. Control neonatal (P3-P5) utricular macula grown in the absence of any growth factor supplement. Some BrdU-labeled cells (green) are located within the sensory epithelium. Most BrdU-labeled SE cells occur in pairs (arrow). Numerous BrdU-labeled cells are present in extrasensory regions of the utricle and they were not quantified. Hair cells are labeled with calretinin (red). The bisbenzimide label is not shown. B. Higher magnification of the region indicated by the arrow in A. All nuclei are labeled blue by bisbenzimide, and the green BrdU-labeled cells are easily visualized. The hair cell label is not shown. The plane of focus is on the supporting cell nuclei.Two presumably postmitotic pairs of BrdU-labeled nuclei are present within the supporting cell layer. C. Neonatal (P3-P5) utricular macula grown in the presence of $\mathrm{HRG}-\alpha(100 \mathrm{ng} / \mathrm{ml})$ showing extensive proliferation in the sensory epithelium (44 labeled nuclei). Two flaps of extrasensory epithelial tissue, a small region on the left and a larger region on the right, contain BrdU-labeled (green) extrasensory cells. Calretinin (red) was used to label the hair cells. Increased numbers of BrdU-labeled cells are seen in the utricular macula of HRG-supplemented cultures vis-à-vis the unsupplemented controls. D Higher magnification of the region indicated by the arrow in C. Many BrdU-labeled nuclei are situated in the hair cell layer, but triple-labeled (BrdU positive, myosin VI positive, and bisbenzimide labeled) cells were not detected, indicating that these cells have not taken on a hair cell phenotype. All BrdU-labeled cells within the sensory epithelium are double labeled (BrdU positive and bisbenzimide labeled), and they are frequently located in pairs or clusters of BrdU-labeled cells. E. Utricular macula from an adult mouse that was cultured for 6 days in the presence of HRG- $\alpha(100$ $\mathrm{ng} / \mathrm{ml}$ ) and BrdU. Hair cells are labeled by myosin VI. BrdU-labeled cells are not seen in the sensory epithelium. Scale bars $=100 \mu \mathrm{m}$ for $\mathbf{A}$ and $\mathbf{B} ; 25 \mu \mathrm{m}$ for $\mathbf{B}, \mathbf{D}$, and $\mathbf{E}$. 


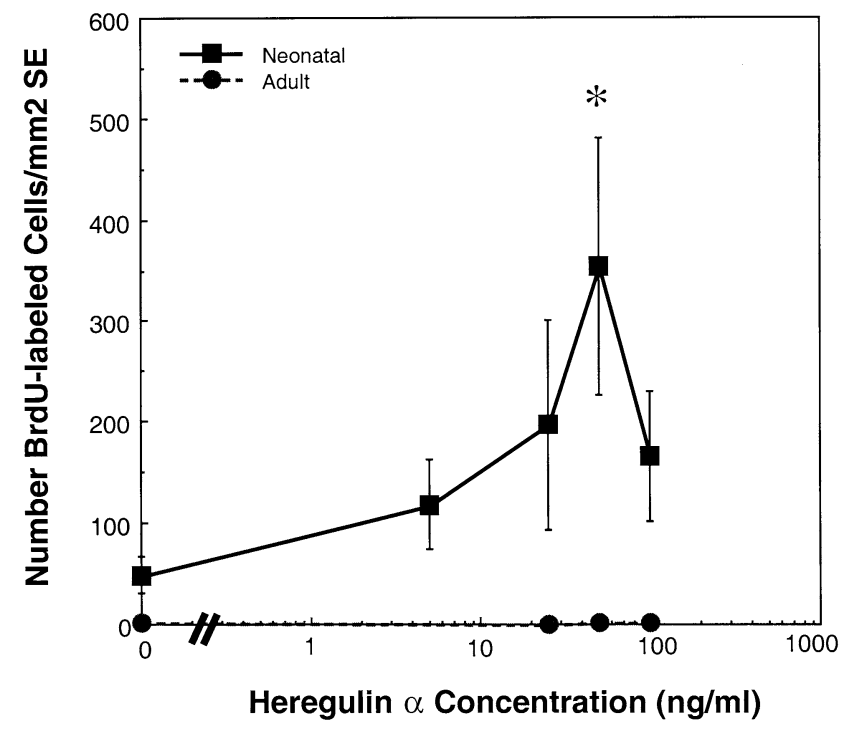

FIG. 3. Quantification of the mitogenic effects of HRG- $\alpha$ on BrdU incorporation in neonatal (P3-P5) and mature mouse utricular maculae cultured for 6 days. BrdU was present the entire incubation period. Each data value represents the mean value \pm SEM of at least 4 specimens from 3 to 4 separate replications (4 replications for neonatal animals; 3 replications for adults) of the experiments. These same data are also expressed as the number of labeled SE cells/ utricle in Table 1 to facilitate comparisons with previous studies (Zheng et al. 1999). An asterisk indicates that the growth factor mean is significantly different from the corresponding control mean at the 0.05 level.

sucrose in phosphate-buffered saline (PBS) overnight. The temporal bones were placed in O.C.T. compound (Miles Laboratories), frozen rapidly with dry ice, and cut into $10-\mu \mathrm{m}$ sections with a cryostat. Sections were mounted onto ethanol/HCL chrome-alum-subbed slides and processed for immunohistochemistry as described below.

Neonatals. The brains from neonatal mice were removed, and the heads were immersed in fixative (4\% paraformaldehyde in $0.1 \mathrm{M}$ phosphate buffer, $\mathrm{pH}$ 7.4) overnight, or for $2 \mathrm{~h}$ in some experiments. After washes in PBS, the temporal bones were dissected free and processed as paraffin or cryostat sections as described earlier. Because the temporal bones of P1-P5 mice are not ossified, decalcification protocols were not used in these experiments.

\section{Antibodies}

Primary antibodies. A panel of antibodies was used to detect EGF receptors. SC-03 (Santa Cruz Biotechnology, Inc., Santa Cruz, CA), a rabbit IgG raised against the C-terminus of human EGFR (identical sequence in mouse), was used at 1:250 to detect erbB1. Western blot analyses carried out by the manufacturer on murine samples have demonstrated that the Santa Cruz SC-03 antibody (as well as the
Santa Cruz erbB2 sc-284, erbB3 sc-285, and erbB4 sc283 antibodies discussed below) does not cross react and recognizes a single protein of the correct size. To detect erbB2, two antibodies were tested, SC-284 (Santa Cruz; rabbit IgG raised against amino acids 1169-1186 of human erbB2) and RB-103-P1 (NeoMarkers, Union City, CA; rabbit anti-erbB2 polyclonal antibody raised against amino acids 1243-1255 from human erbB2). The SC-284 antibody was used routinely (at 1:500) to detect erbB2. The following three antibodies were used to detect erbB3: (1) SC-285 (Santa Cruz; rabbit IgG raised against amino acids $1307-1323$ of human erbB3) was used at 1:250; (2) Ab-236, polyclonal rabbit sera specific for the ligandbinding domain of erbB3 (against amino acids 7186) (kindly provided by Dr. Nita Maihle, Mayo Foundation, Rochester, MN), was used at 1:1000; and (3) an affinity-purified Ab-236 antibody (provided by Dr. Nita Maihle) was used at 1:1000 (Lee and Maihle 1998). To detect erbB4, three antibodies were tested, but two (0616 and 0618) were used routinely. The 0616 and 0618 antibodies (kindly provided by Dr. Cary Lai, Salk Institute) were rabbit IgG raised against different epitopes of the cytoplasmic tail of erbB4, and they were used at dilutions of 1:2500 (0616) and 1:5000 (0618). Antibody 0616 is directed against a sequence that corresponds to residues 1185-1238 in human erbB4 (Plowman et al. 1993); antibody 0618 is directed against a sequence that corresponds to residues 1108-1136 (Plowman et al. 1993). Western blot analyses of the 0616 and 0618 antibodies in mouse (Zhu et al. 1995) have demonstrated that the antibodies react specifically with erbB4 and not with erbB2 or erbB3. The 0616 and 0618 antisera gave similar staining patterns in control tissues and in the ear. SC-283 (Santa Cruz), a rabbit antiserum against human erbB4, was tested but not used routinely because it tended to give high background labeling of nuclei.

To label hair cells in neonatal mice, the following antibodies were used: anti-calretinin antibodies (Chemicon International Inc., Temecula, CA), mouse monoclonal (Catalog No. MAB1568) and rabbit polyclonal (Catalog No. AB149), were used at dilutions of 1:1000 or 1:2000; anti-parvalbumin (Sigma) mouse monoclonal used at a dilution of 1:1000 (Xiang et al. 1998); a rabbit anti-myosin VI polyclonal antibody (kindly provided by Dr. Tama Hasson, University of California-San Diego, La Jolla, CA) (Hasson et al. 1997) was used at 1:500. The myosin VI antibody was also used to label hair cells in adult mice.

A mouse anti-BrdU monoclonal antibody (BectonDickinson, San Jose, CA; Catalog No. 347580) was used at 1:100 to label cells as they passed through $\mathrm{S}$ phase. 

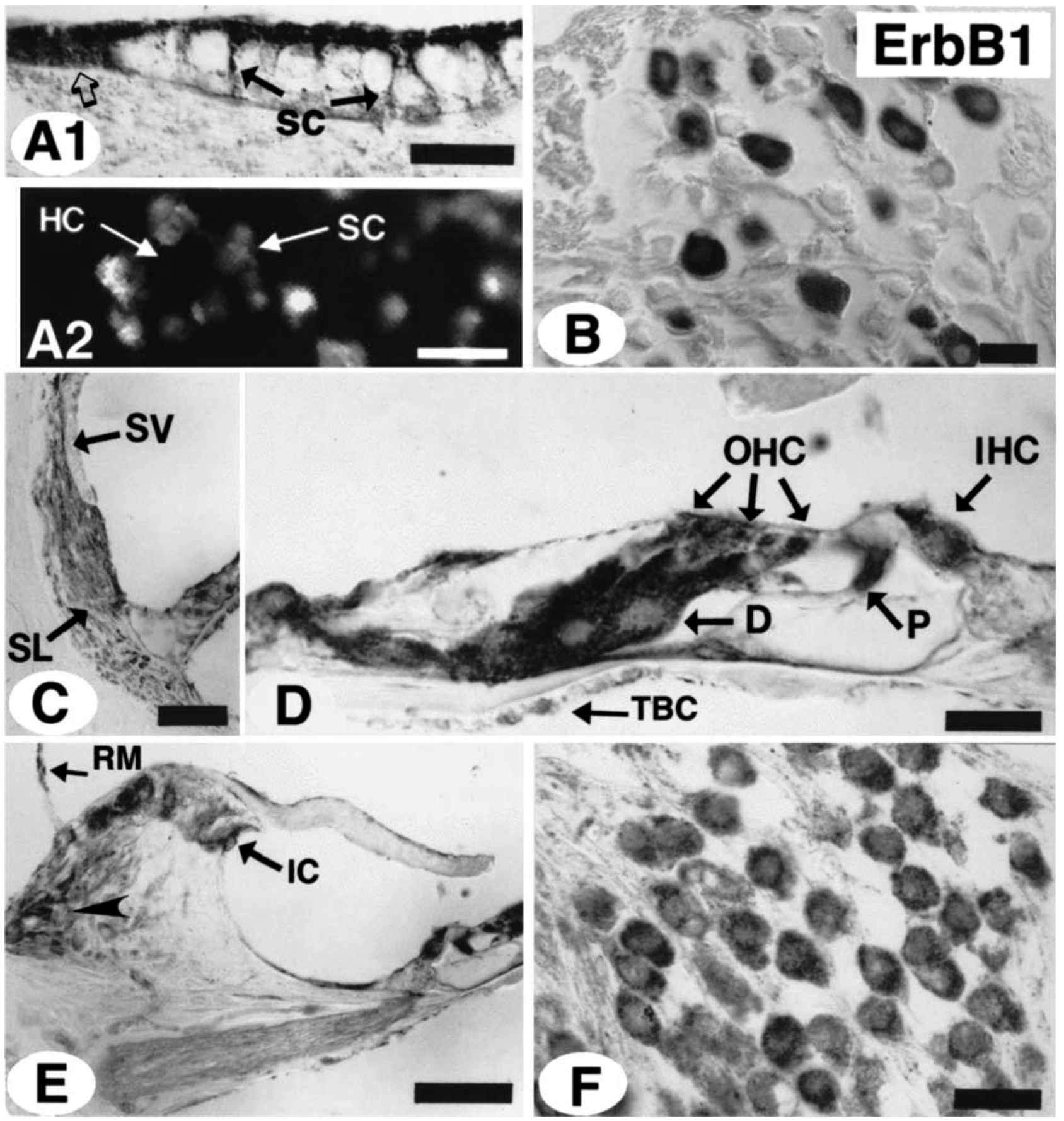

FIG. 4. ErbB1 expression in the adult mouse inner ear. All parts of the figure, with the exception of $\mathbf{A 2}$, were viewed with Nomarski differential-interference contrast optics. A2 was viewed with epifluorescence microscopy. A. Vestibular sensory epithelium. A1. Cross-section of a paraffin-embedded utricle. ErbB1 labels apical and basal regions of the supporting cells (SC). Extrasensory cells within the transitional epithelium (open arrow) are strongly immunopositive. A2. Whole-mount preparation of a utricle immunofluorescently stained for erbB1. The plane of focus is near the reticular lamina. ErbB1 label can be observed in the apical processes of the supporting cells (SC). Hair cells (HC) are unlabeled. B. Cryostat section of the vestibular ganglion. Cell bodies of ganglion cells are strongly immunoreactive for erbB1. C. Spiral ligament (SL)

and stria vascularis (SV) from the apical turn. Numerous fibrocytes located within the spiral ligament are immunostained for erbB1, whereas the stria vascularis is unlabeled. D. Organ of Corti from the apical turn. Immunoreactive label can be seen in the inner (IHC) and outer (OHC) hair cells, Deiters' cells (D), pillar cells (P) and Hensen's cells. Some tympanic border cells (TBC) are also immunopositive for erbB1. E. Spiral limbus from the apical turn. ErbB1 label is visible in some spiral limbus fibrocytes (arrowhead) and in the interdental cells (IC). A small portion of Reissner's membrane (RM) is visible in the figure and it is immunopositive for erbB1. F. Spiral ganglion. Strong erbB1 labeling can be seen in spiral ganglion cell bodies, and the nuclei are unlabeled. Scale bars $=40 \mu \mathrm{m}$ in $\mathbf{C}$ and $\mathbf{E} ; 20 \mu \mathrm{m}$ in $\mathbf{D}, \mathbf{F}$, $\mathbf{A 1}, \mathbf{A 2}$, and $\mathbf{B}$. 

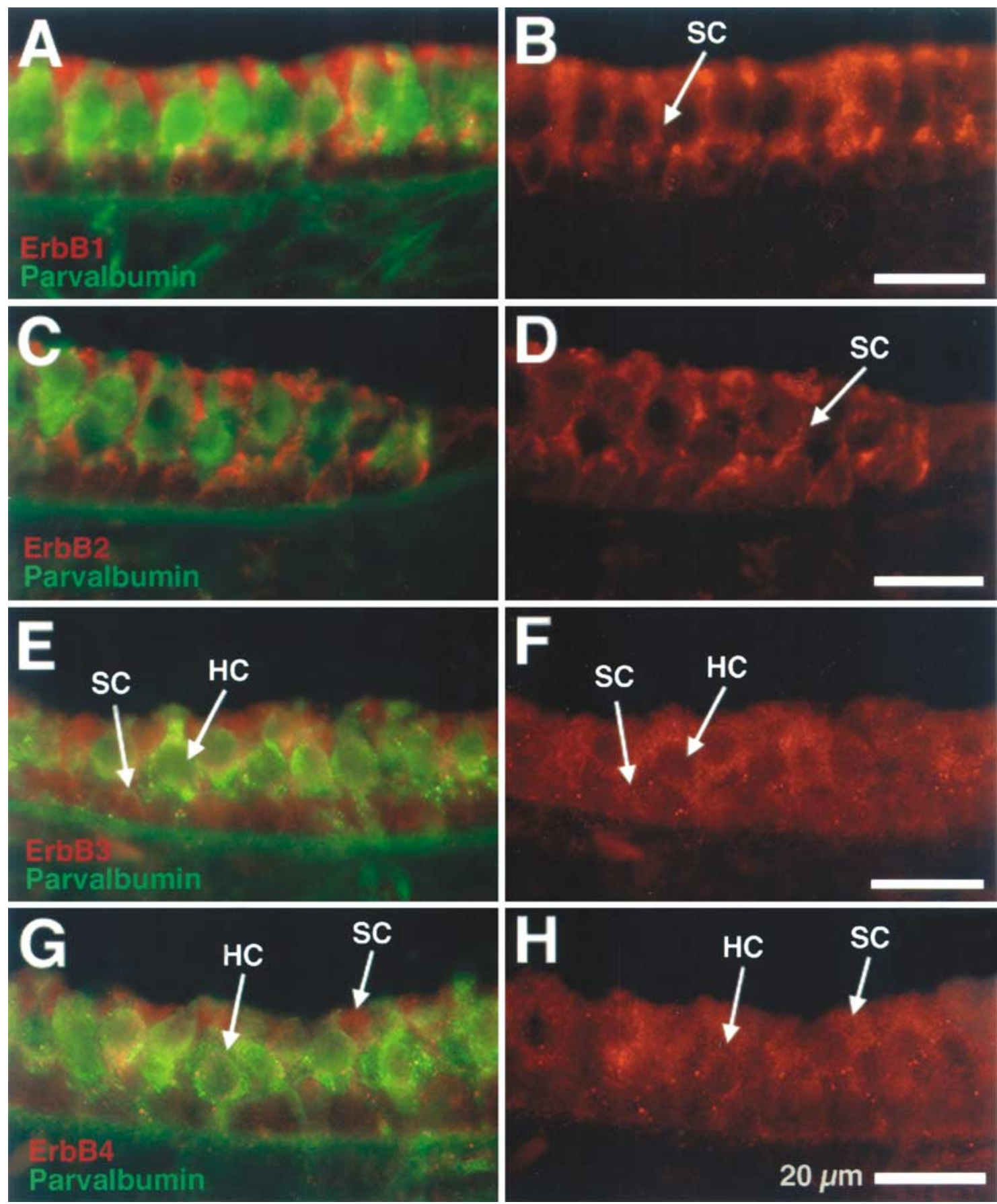

FIG. 5. ErbB 1-4 expression in neonatal mouse utricular sensory epithelium. A-H. Cryostat sections taken from P3-P5 mice viewed with epifluorescence microscopy. The left panel shows double labeling for each erbB (red) and parvalbumin (green), a hair cell marker. The right panel shows erbB labeling alone. A, B. ErbB1: Supporting cells are strongly labeled by erbB 1 , whereas the hair cells and underlying stromal tissue are unlabeled. Lighter label is also

Secondary antibodies. Secondary antibodies were used at dilutions recommended by the manufacturer (1:200). Biotinylated goat anti-rabbit IgG and goat anti-mouse IgG were purchased from Vector Laboratories, Inc. (Burlingame, CA). Goat anti-

seen in the transitional epithelium (not shown). C, D. ErbB2: Supporting cells are strongly immunoreactive, and the labeling extends from the lumenal to basal regions. E, F. ErbB3: Occasional hair cells are heavily labeled, but the majority of hair cells and supporting cells are moderately labeled. G, H. ErbB4: The majority of hair cells and supporting cells are moderately labeled. Scale bars $=20 \mu \mathrm{m}$. Hair cells (HC), supporting cells (SC).

rabbit IgG and goat anti-mouse IgG conjugated with fluorescent labels (Alexa 488, 568, 594, FITC, Bodipy-FL) were purchased from Molecular Probes (Eugene, OR), ICN (Costa Mesa, CA), and Vector Laboratories. 

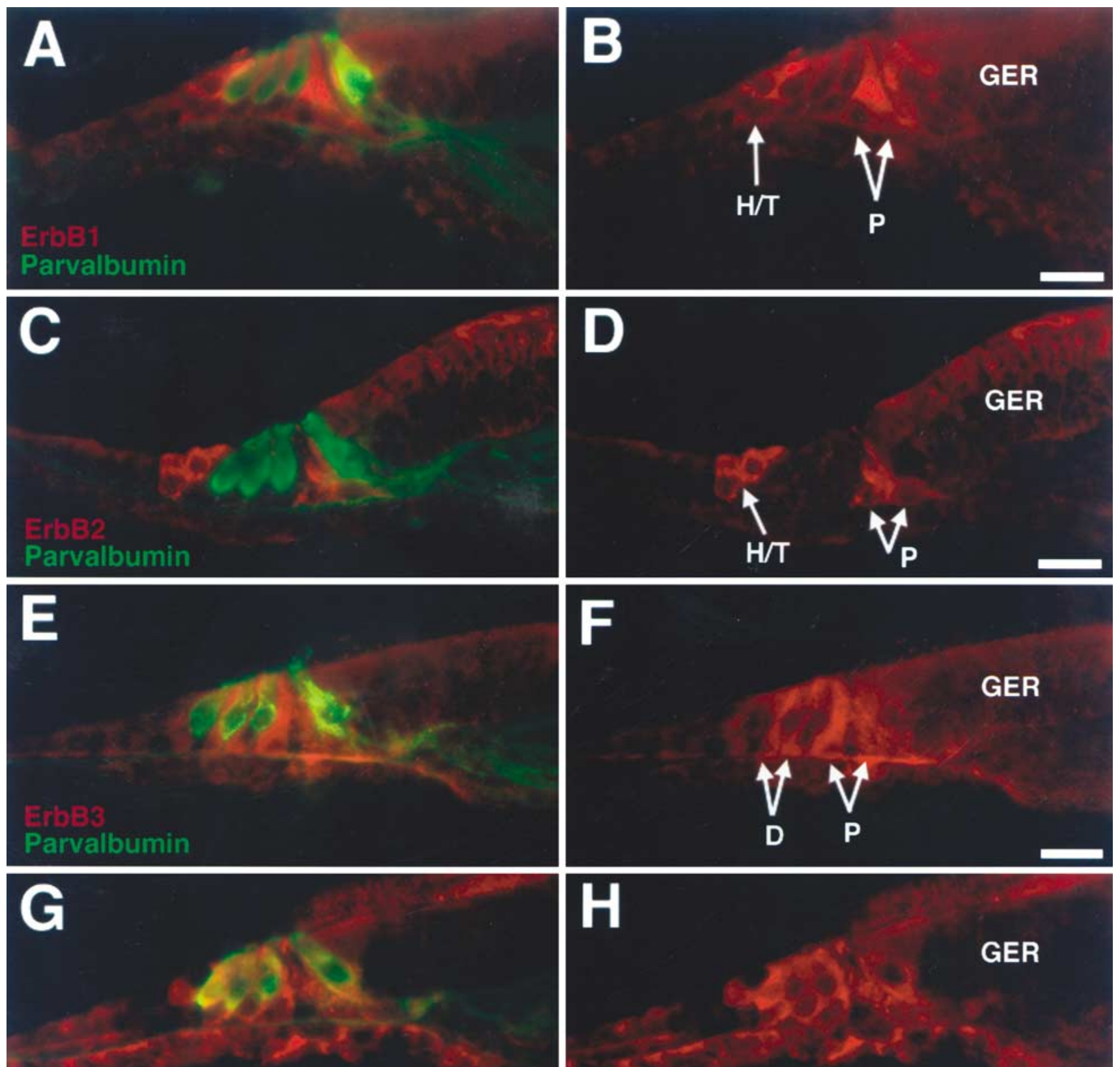

FIG. 6. ErbB 1-4 expression in the neonatal mouse organ of Corti. A-H. Cryostat sections taken from P3-P5 mice viewed with epifluorescence microscopy. The left panel shows double labeling for each erbB (red) and parvalbumin (green), a hair cell marker. The right panel shows erbB labeling alone. A, B. ErbB1: Pillar cells (P) and cells lateral to the OHCs in the Hensen's/tectal cell region $(H / T)$ are strongly labeled. Cells of the greater epithelial ridge (GER) are faintly inununopositive. C, D. ErbB2: Pillar cells and cells lateral to the OHCs are strongly labeled. Cells within the greater epithelial

\section{Immunohistochemical and immunofluorescent staining}

BrdU/hair cell marker/bisbenzimide triple labeling. Utricles were incubated in $1 \mathrm{~N} \mathrm{HCl} / 0.1 \%$ Triton $\mathrm{X}-100$ in

ridge are moderately labeled. E, F. ErbB3: Supporting cells, including Deiters' and pillar cells, are strongly labeled by erbB3. Cells of the greater epithelial ridge are faintly immunopositive. G, H ErbB4: Hair cells and supporting cells are strongly immunopositive for erbB4. Cells of the greater epithelial ridge are more lightly labeled. Labeling is also noted in cells under the basilar membrane, tympanic border cells. Scale bars $=20 \mu \mathrm{m}$. Greater epithelial ridge (GER), pillar cells $(\mathrm{P})$, Hensen's/tectal cells $(\mathrm{H} / \mathrm{T})$, Deiters' cells $(\mathrm{D})$.

PBS at $37^{\circ} \mathrm{C}$ for 30 min to denature DNA. After neutralizing washes in PBS ( $\mathrm{pH} 8.5 / \mathrm{pH} \mathrm{7.4),} \mathrm{the} \mathrm{tissue}$ was treated for $3 \mathrm{~h}$ with $0.1 \%$ saponin $/ 0.1 \%$ Tween 20 in PBS in order to make membranes more permeable 

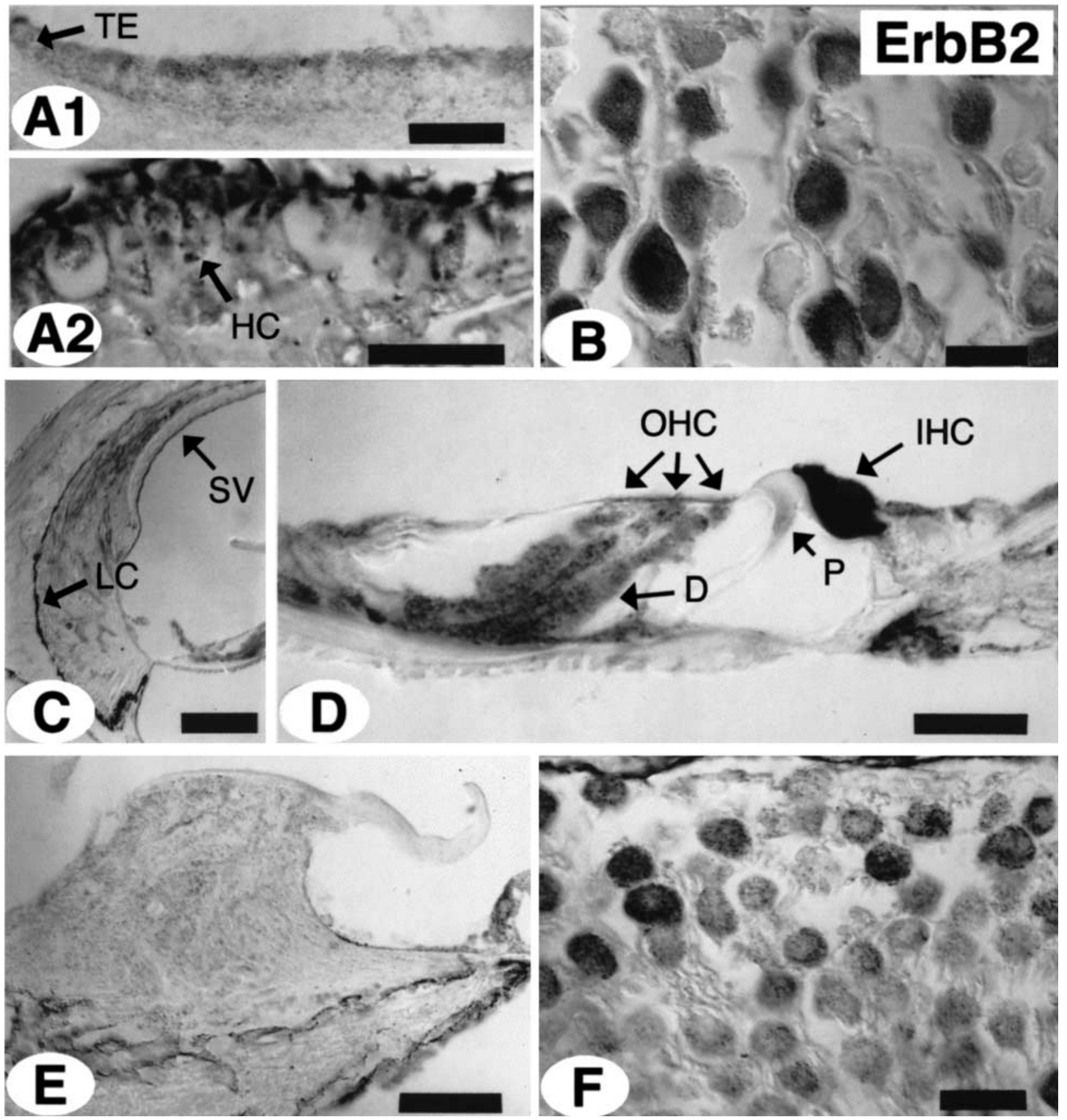

FIG. 7. ErbB2 expression in the adult mouse inner ear. A-F. Viewed with Nomarski differential-interference contrast optics. A. Vestibular sensory epithelia. A1. Utricular maculae and adjacent transitional epithelium (TE). The transitional epithelium and lumenal surface of the utricular maculae are immunopositive for erbB2. A2. Crista ampullaris. Hair cells (HC) are immunopositive. The labeling of the stereocilia was also seen in control tissue. B. Vestibular ganglion. A subset of the vestibular ganglion neurons is labeled. C. Spiral ligament and stria vascularis (SV) from the apical turn. The

to antibodies. Tissues were then incubated overnight in $10 \%$ normal goat serum $/ 0.03 \%$ saponin $/ 0.1 \%$ Triton X-100 in PBS. The following primary antibodies stria vascularis is unlabeled for erbB2, whereas fibrocytes within the spiral ligament are immunopositive, and the cells lining the bone (LC) are strongly labeled. D. Basal turn organ of Corti. Inner hair cells (IHC) are strongly labeled for erbB2. D, Deiters' cells; OHC, outer hair cells; P, Pillar cell. E. Spiral limbus in the basal turn. ErbB2 labeling is undetectable in the spiral limbus. F. Spiral ganglion from the basal turn of the cochlea. A subset of thespiral ganglion cell neurons is labeled. Scale bars $=40 \mu \mathrm{m}$ in $\mathbf{C}$ and $\mathbf{E} ; 20 \mu \mathrm{m}$ in $\mathbf{A}, \mathbf{B}, \mathbf{D}$, and $\mathbf{F}$.

were added simultaneously: mouse anti-BrdU and either rabbit anti-calretinin (P3-P5 utricles) or rabbit anti-myosin VI (4-6-week utricles) to label hair cells as 

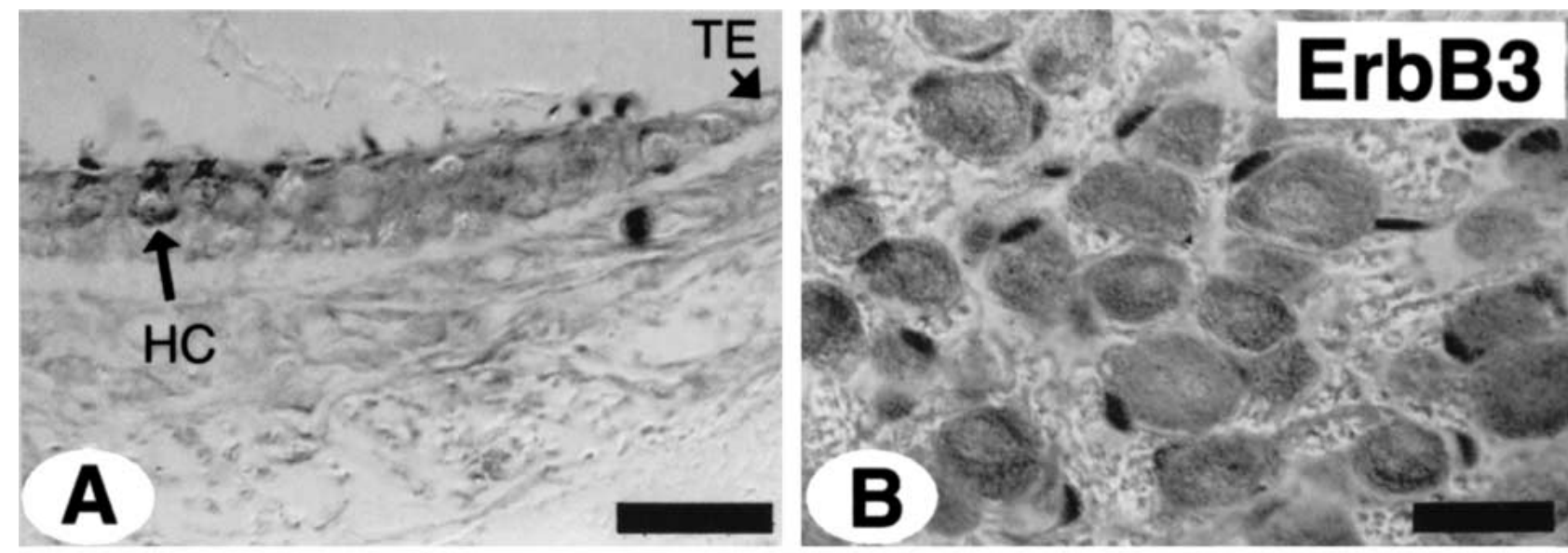
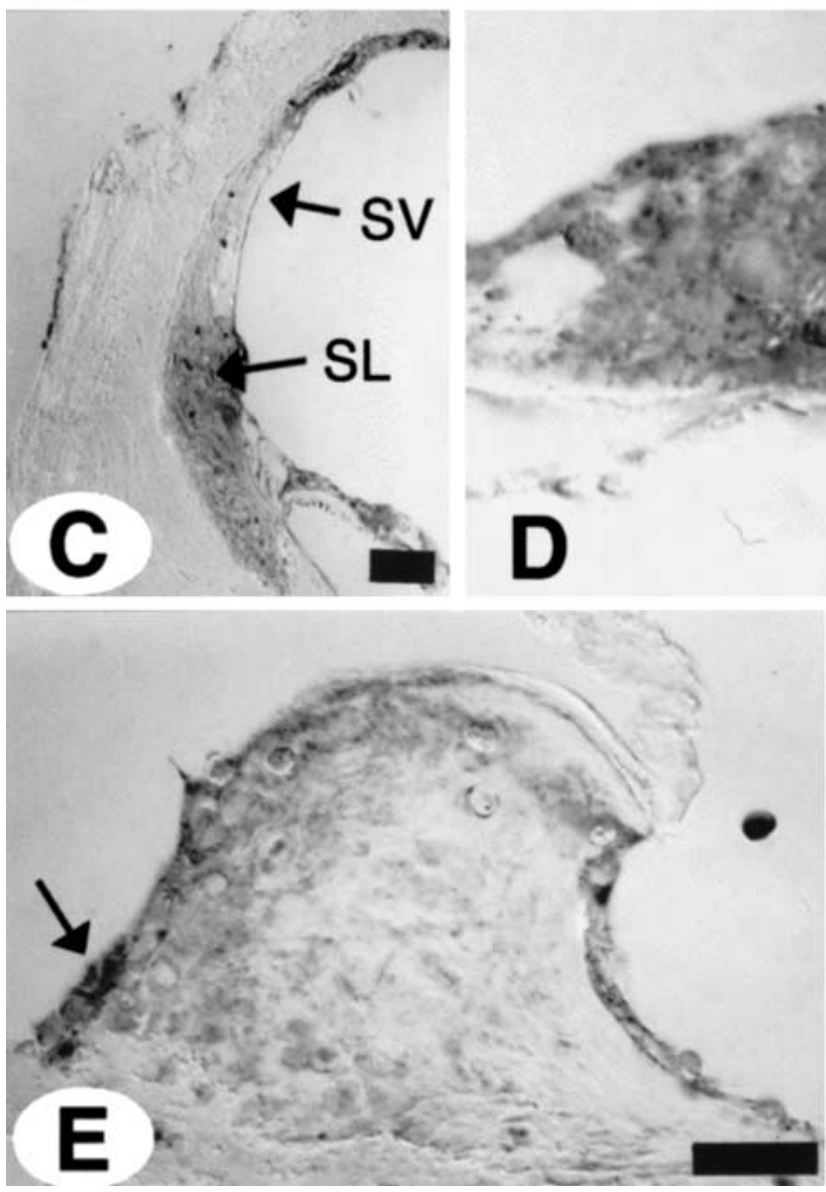

FIG. 8. ErbB3 expression in the adult mouse inner ear. A-F. Viewed with Nomarski differential-interference contrast optics. A. Utricular macula. A subset of vestibular hair cells (HC), presumably Type I hair cells, is labeled with erbB3. TE, Transitional epithelium. B. Vestibular ganglion. Vestibular ganglion neurons and satellite cells are immunopositive. C. Spiral ligament (SL) and stria vascularis (SV) in

described above. The primary antibodies were diluted in $3 \%$ normal goat serum $/ 0.03 \%$ saponin $/ 0.1 \%$ Triton $\mathrm{X}-100$ in PBS, and the tissues were incubated overnight at $4^{\circ} \mathrm{C}$. After three 15-min washes with $0.1 \%$ Tween 20 in PBS, tissue was incubated simultaneously

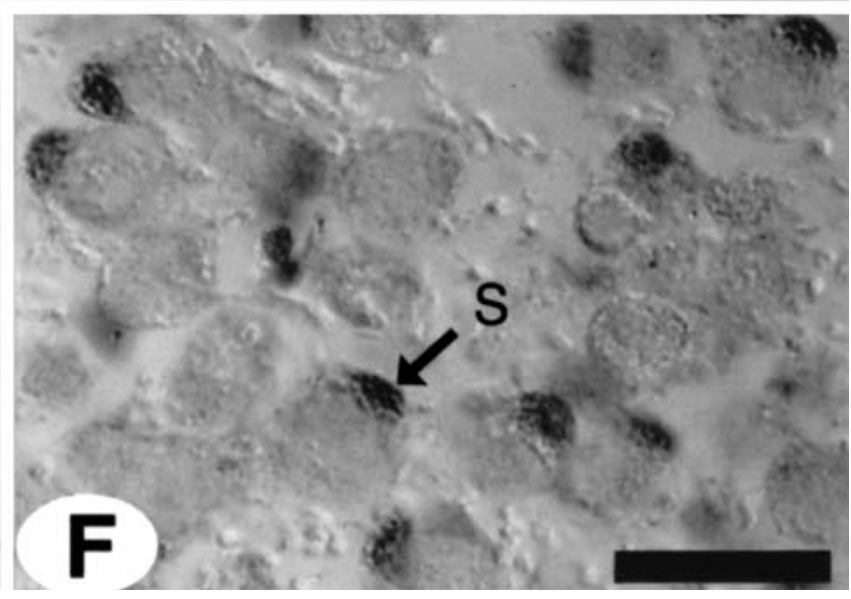

the apical turn. D. Cryostat section of the apical turn organ of Corti. Faint erbB3 labeling is seen throughout the organ of Corti. E. Basal turn spiral limbus. Some cells near the attachment of Reissner's membrane (arrow) are strongly labeled with erbB3. F. Spiral ganglion at the apical turn. Satellite cells $(\mathrm{S})$ are strongly immunopositive for erbB3. Scale bars $=40 \mu \mathrm{m}$ in $\mathbf{C} ; 20 \mu \mathrm{m}$ in A, B, D-F.

with both fluorescently labeled secondary antibodies for $4 \mathrm{~h}$ at room temperature in $3 \%$ normal goat serum $/ 0.03 \%$ saponin $/ 0.1 \%$ Triton X-100 in PBS. After 15-min wash in PBS with $0.1 \%$ Tween 20, the utricles were immersed for $15 \mathrm{~min}$ in the dark in bisbenzimide 

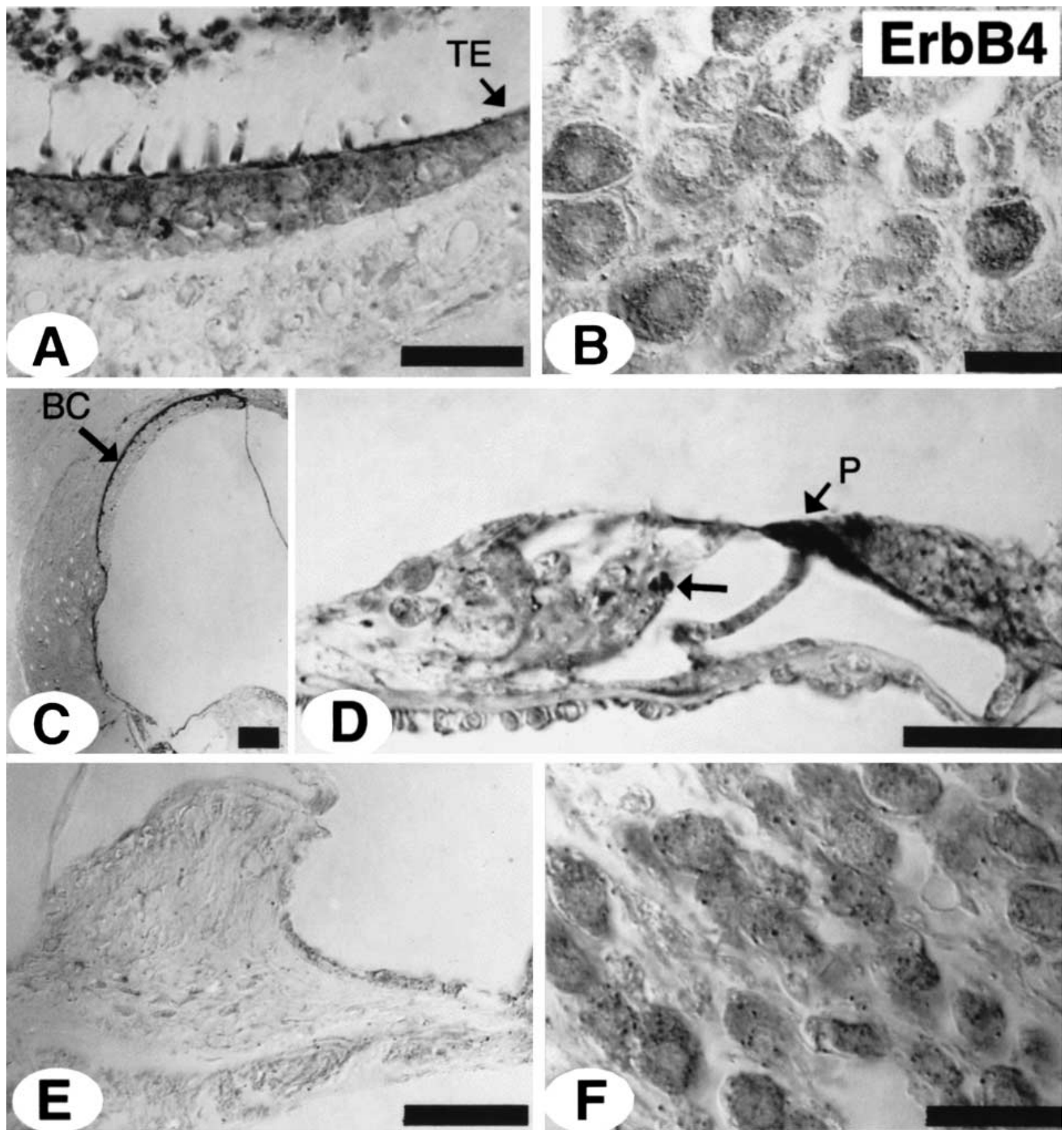

FIG. 9. ErbB4 expression in the adult mouse inner ear. A-F. Viewed with Nomarski differential-interference contrast optics. A. Vestibular sensory epithelium: Hair cells and supporting cells are immunopositive for erbB4. TE, Transitional epithelium. B. Vestibular ganglion. Some vestibular ganglion neuron cell bodies are strongly labeled for erbB4. C. Spiral ligament and stria vascularis in the basal turn of the cochlea. Basal cells (BC) in the stria vascularis are also

(Hoechst 33342, Sigma, 1:200) in order to label nuclei. Finally, the organs were washed (3 times for 10 min each) in PBS, placed on glass slides as whole mounts using $1 \%$ DABCO (Sigma) in glycerol, and coverslipped.

strongly labeled for erbB4. D. Apical turn organ of Corti. Neural endings under the OHCs (arrow) and in the IHC area are immunopositive for erbB4. P, pillar cell. E. Apical turn spiral limbus. ErbB4 label is undetectable in the spiral limbus. F. Spiral ganglion in the apical turn of the cochlea. Numerous neural cell bodies are moderately labeled for erbB4. Scale bars $=40 \mu \mathrm{m}$ in $\mathbf{C}$ and $\mathbf{E} ; 20 \mu \mathrm{m}$ in $\mathbf{A}, \mathbf{B}, \mathbf{D}$ and $\mathbf{F}$.

ErbB immunohistochemical staining. For the halftemporal-bone preparations, endogenous peroxidase activity was quenched by a $1-\mathrm{h}$ incubation in $3 \%$ hydrogen peroxide, prior to antibody reactions. Primary and secondary antibody incubations were 
performed for 3-5 days each at $4^{\circ} \mathrm{C}$ in $\mathrm{PBS}, 0.03 \%$ saponin, $10 \%$ goat serum, $2 \mathrm{mg} / \mathrm{ml}$ bovine serum albumin, and $0.1 \%$ Triton $\mathrm{X}-100$ with gentle agitation. Biotinylated secondary antibodies (1:200) were detected using the Vectastain Elite ABC kit (Vector Laboratories). Incubation with the $\mathrm{ABC}$ reagent was for 2 days. Bound antibody was visualized with 3-3' diaminobenzidene (DAB). Stained temporal bones and retinae were embedded in Paraplast (Oxford Labware, St. Louis, MO) and sectioned.

Immunohistochemistry was also performed on paraffin and/or cryostat sections with the following modifications: (1) Endogenous peroxidase activity was quenched in $1 \% \mathrm{H}_{2} \mathrm{O}_{2}$ for $30 \mathrm{~min}$; (2) the primary antibodies were incubated with sections overnight at $4^{\circ} \mathrm{C}$; and (3) secondary and $\mathrm{ABC}$ incubations were for $2 \mathrm{~h}$ at room temperature in the same buffers.

ErbB immunofluorescent staining. Paraffin or cryostat sections were prepared for immunofluorescence as described above, omitting the peroxidase-quenching step. Primary and secondary antibody incubations were performed for 1 day and $2 \mathrm{~h}$, respectively, at $4^{\circ} \mathrm{C}$ in PBS, $0.03 \%$ saponin, $3 \%$ goat serum, $2 \mathrm{mg} / \mathrm{ml}$ bovine serum albumin, and $0.1 \%$ Triton X-100 with gentle agitation. Fluorescently labeled secondary antibodies (Alexa 488, 594, Molecular Probes) were used at a dilution of 1:200. In double-labeling experiments, sections were labeled simultaneously with both a rabbit anti-erbB antibody and a mouse antiparvalbumin or anti-calretinin antibody (to identify hair cells). Fluorescent secondary antibodies were also incubated simultaneously in the double-labeling experiments. Sections were washed after each antibody incubation (3 times for $10 \mathrm{~min}$ each) in $0.1 \%$ Tween 20 in PBS. Sections were mounted in Vectashield (Vector Laboratories) and examined with epifluorescence.

For whole-mount labeling of utricles, otoconia were manually removed after fixation, and the utricles were incubated with primary antibodies as described for the half-temporal-bone preparations. Fluorescently labeled secondary antibody (Alexa 568, 594, 488 and Bodipy-FL, Molecular Probes) incubations were for 1-2 days at $4^{\circ} \mathrm{C}$. After counterstaining nuclei with bisbenzimide (1 $\mu \mathrm{g} / \mathrm{ml})$, specimens were mounted in Vectashield and examined with either epifluorescence or confocal fluorescence microscopy.

Controls for immunohistochemistry/immunofluorescence. Method and antibody specificity were checked by (1) substituting nonimmune sera for the primary antibody, (2) blocking with the immunizing peptide when available (e.g., erbBs 1-3, Santa Cruz), (3) using a series of dilutions of the primary antibody, and (4) processing positive control tissues (mouse retina) alongside the inner ear tissue. Others have previously shown that erbB receptors have distinct tissue expression profiles in postnatal and adult rodent retina (Anchan et al. 1991; Lillien 1995; BerminghamMcDonogh et al. 1996). The specificity of these antierbB antibodies has been demonstrated previously in the adult rat and chinchilla inner ear (Matsunaga et al. 2001, Zhang et al. 2002). In double-labeling experiments, only antibodies raised in different species were used to avoid cross reactivity among the antibodies (e.g., mouse anti-BrdU was used with rabbit anti-calretinin). For both adult and neonatal animals, the antibody staining using immunofluorescent and immunohistochemical detection methods was consistent (not shown).

\section{Data analysis}

Whole-mount utricle preparations were viewed under epifluorescence on a Nikon Optiphot microscope with 10X (0.25 NA), 20X (0.4 NA) or 40X (0.65 NA) objectives, and images were captured with a Spot $2 \mathrm{e}$ camera (Diagnostics Instruments, Sterling Heights MI). The number of BrdU-labeled cells located within the sensory receptor epithelium, the utricular macula, was quantified for each utricle. The lateral borders of the sensory epithelium (i.e., sensory epithelium vs. transitional epithelium) are defined by the outermost hair cells (visualized by calretinin or myosin VI labeling). The bottoms of the supporting cell nuclei define the lower boundary of the sensory epithelium (sensory epithelium vs. underlying stromal tissues). All nuclei are labeled with bisbenzemide, and the densely packed supporting cell nuclear layer is easily discerned from the overlying, more sparsely packed hair cell nuclear layer and the underlying stromal tissue. The distinction between the sensory epithelial and stromal cell layers is rigorously maintained. We and others have previously shown that these layers can be routinely identified in whole-mount preparations based on the size, shape, and density of the labeled nuclei, as well as depth within the epithelium (Stone and Cotanche 1994; Warchol and Corwin 1996; Oesterle et al. 1997). Within the sensory epithelium, hair cell nuclei are larger in size and more spherically shaped than the smaller, oval-shaped supporting cell nuclei.

In the current studies, for each BrdU-labeled cell it was noted whether the labeled cell was double-labeled by the hair cell-specific marker and whether it occurred in a pair of BrdU-labeled cells, or as part of a cluster. Pairs of BrdU-labeled nuclei were defined as " two BrdU-labeled nuclei separated by a distance not more than twice the diameter of two nuclei." Clusters of BrdU-labeled cells were defined as "three or more BrdU-labeled nuclei separated by a distance not more than twice the diameter of two nuclei." 
The area of each utricular macula was quantified by using Object Image 2.04e (written by Norbert Vischer, available from simon.biol.uva.nl), and the amount of BrdU labeling was expressed as the number of BrdU-labeled cells $/ \mathrm{mm}^{2}$ of sensory epithelium (SE). Data from individual utricles were averaged to yield an average number of BrdU-labeled cells $/ \mathrm{mm}^{2}$ SE for each experimental paradigm \pm the standard error of the mean (SEM). Utricles with less than half of the SE $\left(50,000 \mu \mathrm{m}^{2}\right)$ visible (e.g., as the result of tissue folding, an overlying flap of tissue, dissection damage, etc.) were excluded and were not included in the averages. Image enhancement and merging of images was performed with Adobe Photoshop 5.5 (Adobe, Seattle, WA).

Significance values were determined with one-way analyses of variance (ANOVAs), and two-group comparisons were determined with $t$ tests or with the Mann-Whitney $U$ test (StatView 5.0, SAS Institute, Inc., Cary, NC). Post hoc comparisons, where appropriate, used the Fisher's Protected LSD, Duncan New Multiple Range, and Tukey-Kramer tests.

\section{RESULTS}

Heregulin- $\alpha$ stimulates proliferation in cultured utricular maculae from neonatal, but not adult, mice

We examined HRG- $\alpha$ 's effect on cell proliferation in the utricular macula of organotypic preparations of neonatal and adult mouse utricles. Utricles were cultured for 6 days in BrdU-supplemented medium (with or without test growth factor present), fixed, and immunofluorescently processed for BrdU and a hair cell-specific marker (calretinin or myosin VI) (e.g., Fig. 2A). Nuclei were counterstained with bisbenzimide (e.g., Fig. 2B).

Neonatals. A cultured control neonatal mouse utricle (no growth factor supplement) is shown in Figure 2A, B. Figure 2B is a higher magnification of the region in Figure 2A specified by the arrow. The green BrdU-labeled nuclei are easily distinguishable from the blue, bisbenzimide-labeled, non-BrdU-labeled nuclei. Few BrdU-labeled nuclei are seen in the sensory epithelium of the control utricle. An organ cultured identically to the control utricle, except that it was grown in the presence of $100 \mathrm{ng} / \mathrm{ml} \mathrm{HRG-} \alpha$, is shown in Figures 2C and D. Figure 2D is a higher magnification of the region of Figure 2C specified by the arrow. A greater number of BrdU-labeled SE cells are present in the HRG- $\alpha$-supplemented utricle than in the unsupplemented control.

The number of cells in the sensory epithelium synthesizing DNA during the 6-day culture period and macular area were quantitatively assessed in 7 unsupplemented (control) and 26 normal HRG- $\alpha$ supplemented utricles. The mean numbers of BrdUlabeled SE cells per utricle, or per $\mathrm{mm}^{2} \mathrm{SE}$, are listed in Table 1, and the mean numbers of BrdU-labeled cells $/ \mathrm{mm}^{2} \mathrm{SE}$ are shown in Figure 3 . When these and other data are expressed as a function of SE area, it facilitates comparisons across species, as well as across different inner ear epithelia (e.g., vestibular vs. auditory). The neonatal utricular macula has a mean area of $101,084 \mu \mathrm{m}^{2}\left( \pm 28,600 \mu \mathrm{m}^{2} \mathrm{SD}, n=33\right)$. The addition of HRG- $\alpha$ increased the number of BrdUlabeled cells in a dose-dependent manner. While there were approximately $48.6 \pm 19.8$ SEM $(n=7)$ proliferative cells $/ \mathrm{mm}^{2} \mathrm{SE}$ in the control utricles, $353.9 \pm 126.6 \quad(n=7) \quad$ BrdU-labeled cells $/ \mathrm{mm}^{2}$ SE were observed in the cultures supplemented with 50 $\mathrm{ng} / \mathrm{ml}$ HRG- $\alpha$. The addition of $50 \mathrm{ng} / \mathrm{ml}$ of HRG- $\alpha$ significantly increased $(p<0.05)$ the numbers of SE cells synthesizing DNA, a sevenfold increase was observed vis-ai-vis controls. Labeled cells were found in both supporting cell and hair cell layers in control and HRG- $\alpha$ supplemented cultures. However, all BrdU-positive SE cells were calretinin negative, indicating that the proliferating cells did not acquire a hair cell phenotype by 6 days in culture. Most labeled cells were found in either pairs or clusters (Table 2), suggesting that many labeled cells are postmitotic pairs.

Adults. The HRG- $\alpha$ experiments were repeated on utricles from mature mice to determine whether the HRG mitogenicity was maintained in the mature sensory epithelium. Utricles from 4-6-week-old mice were cultured for 6 days in BrdU-supplemented medium in the presence or absence of HRG- $\alpha$. The number of cells in the SE synthesizing DNA during the 6-day culture period and macular area were quantitatively assessed in 10 unsupplemented (control) and 20 HGR- $\alpha$-supplemented utricles. The adult utricular macula has a mean area of 108,503 $\mu \mathrm{m}^{2}\left( \pm 29,147 \mu \mathrm{m}^{2} \mathrm{SD}, n=30\right)$ and does not differ significantly in size from that of neonatal mice $(p>$ $0.05)$. In contrast to the findings in neonatal mice, ongoing proliferation was not observed in the sensory epithelium of the mature mice; virtually no BrdU-labeled cells were seen $($ mean $=1.0 \pm 1.0 \mathrm{SEM}$ BrdU-labeled cells $/ \mathrm{mm}^{2} \mathrm{SE} ; 1$ labeled cell was seen in 10 utricular maculae) (Fig. 2E). Numbers of BrdU-labeled SE cells differed significantly $(p<0.01)$ in neonatal and mature control utricular maculae, demonstrating age-dependent differences in the amount of ongoing proliferation in mice utricles. Furthermore, in contrast to the findings in neonatals, addition of HRG- $\alpha(25,50,100 \mathrm{ng} / \mathrm{ml})$ to mature utricular maculae did not potentiate SE cell proliferation (Fig. 3, Table 1). 


\begin{tabular}{|c|c|c|c|c|}
\hline \multicolumn{5}{|c|}{ TABLE 1} \\
\hline \multicolumn{5}{|c|}{ Effect of HRG- $\alpha$ on SE cell proliferation } \\
\hline Growth factor (age) & Concentration $(\mathrm{ng} / \mathrm{ml})$ & $n$ & $\begin{array}{c}\text { Mean No. LC/macula }{ }^{a} \\
\pm S E M\end{array}$ & $\begin{array}{c}\text { Mean No. } L C / \mathrm{mm}^{2} S E^{a} \\
\pm S E M\end{array}$ \\
\hline $\mathrm{HRG}-\alpha(\mathrm{P} 3-5)$ & 0 & 7 & $4.9 \pm 2.0$ & $48.6 \pm 19.8$ \\
\hline & 5 & 9 & $9.8 \pm 2.9$ & $118.4 \pm 47.7$ \\
\hline & 25 & 6 & $21.3 \pm 12.7$ & $197.2 \pm 113.9$ \\
\hline & 50 & 7 & $30.4 \pm 9.3^{*}$ & $353.9 \pm 126.6^{*}$ \\
\hline & 100 & 4 & $20.7 \pm 8.3$ & $165.9 \pm 73.2$ \\
\hline HRG- $\alpha$ (4-6 wks) & 0 & 10 & $0.1 \pm 0.1$ & $1.0 \pm 1.0$ \\
\hline & 25 & 6 & $0 \pm 0$ & $0 \pm 0$ \\
\hline & 50 & 8 & $0.1 \pm 0.1$ & $1.7 \pm 1.8$ \\
\hline & 100 & 6 & $0.2 \pm 0.2$ & $1.2 \pm 1.3$ \\
\hline
\end{tabular}

a $\mathrm{LC}=$ BrdU-labeled cell.

*Significant from controls at the 0.05 level.

\section{TABLE 2}

BrdU-labeled SE cells located in pairs and clusters as percentage of the total number of BrdU-labeled SE cells

\begin{tabular}{ccc}
\hline $\begin{array}{c}\text { HRG- } \alpha \text { concentration } \\
(\mathrm{ng} / \mathrm{ml})\end{array}$ & $\begin{array}{c}\text { Cells in } \\
\text { pairs }(\%)\end{array}$ & $\begin{array}{c}\text { Cells in } \\
\text { clusters }(\%)\end{array}$ \\
\hline 0 & 59 & 18 \\
5 & 51 & 30 \\
25 & 29 & 57 \\
50 & 23 & 71 \\
100 & 47 & 39 \\
\hline
\end{tabular}

Heregulin binding receptors are expressed in neonatal and adult inner ear

To determine whether downregulation of receptor expression was responsible for loss of the mitogenic response to HRG- $\alpha$ in the utricular sensory epithelium, we examined the distribution of erbBs in the inner ears of mice of comparable age to our culture experiments using immunohistochemistry/immunofluorescence and well-characterized polyclonal antisera specific for each receptor. We also examined erbB expression in the spiral and vestibular ganglia and in extrasensory tissues (spiral limbus, spiral ligament, stria vascularis, transitional epithelium) of adult mice.

\section{ErbB1}

\section{Vestibular end organs}

Adult. ErbB1 (EGFR) expression was examined in the vestibular end organs, and similar patterns of expression are found in the utricle, saccule, and cristae ampullaris. There is strong erbB1 labeling at the apical surface of the vestibular sensory epithelium that extends laterally into the extrasensory transitional zone lacking hair cells (Fig. 4A1). Supporting

\section{TABLE 3}

Summary table: ErbB expression in neonatal and adult vestibular sensory epithelia ${ }^{a}$

\begin{tabular}{lccccccr}
\hline & \multicolumn{3}{c}{ Adult } & & \multicolumn{3}{c}{ Neonatal } \\
\cline { 2 - 6 } & HC & $S C$ & TE & HC & SC & $T E$ \\
\cline { 2 - 6 } & ErbB1 & & + & + & & + & + \\
ErbB2 & + & + & + & & + & + \\
ErbB3 & + & & & & + & + & + \\
ErbB4 & + & + & + & + & + & + \\
\hline
\end{tabular}

${ }^{\mathrm{a}} \mathrm{HC}=$ hair cell, $\mathrm{SC}=$ supporting cell, $\mathrm{TE}=$ transitional epithelium.

cells in both the otolithic organs and the cristae are immunoreactive for erbB1. ErbB1 labeling in the supporting cells extends from their apical processes at the reticular lamina down toward their bases that contact the basement membrane. In contrast, vestibular hair cells are unlabeled. This can be seen more clearly in an immunofluorescently stained wholemount utricular preparation showing a rosette of labeled supporting cells surrounding an unlabeled hair cell (Fig. 4A2). Within the vestibular ganglion (Fig. 4B), erbB1 immunoreactivity is found in a subset of sensory neuron cells.

Neonatal. The supranuclear region of supporting cells in the vestibular sensory epithelia of P3-P5 mice is strongly labeled for erbB1 (Fig. 5A, B). Low levels of erbB1 label are present in the stroma (data not shown).

\section{Organ of Corti}

Adult. In the cochlea, erbB1 is expressed in both sensory and nonsensory cells. The strongest labeling is noted in Deiters' cells and inner hair cells (IHCs) (Fig. 4D). In these cell types, the labeling appears to be distributed relatively uniformly from the basal to apical regions of the cells. Inner hair cell stereocilia 
TABLE 4

Summary table: ErbB expression in neonatal and adult auditory sensory epithelial ${ }^{\mathrm{a}}$

\begin{tabular}{|c|c|c|c|c|c|c|c|c|}
\hline & \multicolumn{4}{|c|}{ Adult } & \multicolumn{4}{|c|}{ Neonatal } \\
\hline & $H C$ & $S C$ & Lateral & Medial & $H C$ & $S C$ & Lateral & Medial \\
\hline$\overline{\text { ErbB1 }}$ & + & + & + & + & & + & & + \\
\hline ErbB2 & + & + & + & + & & + & & + \\
\hline ErbB3 & + & + & + & + & + & + & + & + \\
\hline ErbB4 & & + & & & + & + & + & + \\
\hline
\end{tabular}

${ }^{\mathrm{a}} \mathrm{HC}=$ haircell, $\mathrm{SC}=$ supporting cell, Lateral = nonsensory epithelia lateral to the organ of Corti (e.g., Claudius' cells, Boettcher's cells), Medial = nonsensory epithelia medial to the organ of Corti (e.g., inner sulcus cells, greater epithelial ridge cells).

are unlabeled. In contrast, in the pillar cells the labeling is not distributed uniformly; labeling of the apical portion of the stalks is more intense. ErbB1 labeling of outer hair cells (OHCs) is consistently more moderate than either IHC or Deiters' cell labeling (Fig. 4D). Hensen's cells are labeled more faintly than the neighboring Claudius' cells (data not shown). Immunoreactivity for erbB1 is also present in other nonsensory cell types, such as the inner sulcus cells (data not shown), the interdental cells of the spiral limbus (Fig. 4E), cells of the spiral ligament (Fig. 4C), and Reissner's membrane (Fig. 4E). ErbB1 labeling is absent from the stria vascularis and basilar membrane. The tympanic border cells that line the underside of the basilar membrane and face the scala tympani are faintly labeled for erbBl (Fig. 4D). When comparing apical and basal turns of the cochlea, no consistent differences were found in the level of erbB1 immunoreactivity in either sensory or extrasensory cells. Within the spiral ganglion (Fig. 4F), erbB1 labeling is found in the majority of sensory neuron cells.

Neonatal. ErbB1 is expressed in supporting cells in the basal and apical turns of the neonatal organ of Corti (P3-P5) (Fig. 6A). The strongest labeling is found in the supporting cells immediately lateral to the OHCs (Hensen's/tectal cell region) and the pillar cells. Immunoreactivity for erbB1 is also present in the cells of the greater epithelial ridge.

\section{ErbB2}

\section{Vestibular end organs}

Adult. ErbB2, like erbB1, is expressed in the vestibular periphery. We consistently find labeling of the reticular lamina in the sensory receptor epithelia of each of the vestibular organs (cristae, saccule, and utricle). Transitional epithelial cells bordering the sensory epithelium are also labeled (Fig. 7A1). In the ampullary organs, erbB2 labeling of hair cells was observed (Fig. 7A2). The labeling of the stereocilia was also seen in control tissue. The cell bodies of many sensory neurons in the vestibular ganglion are also strongly labeled for erbB2 (Fig. 7B).

Neonatal. ErbB2 antibodies label vestibular supporting cells in sensory epithelia of P3-P5 mice (Fig. $5 \mathrm{C}, \mathrm{D})$. Apical and basal regions of the supporting cell cytoplasm are labeled and the supporting cell nuclei are unlabeled.

\section{Organ of Corti}

Adult. ErbB2 immunoreactivity is detected in both sensory and nonsensory cell types in the adult organ of Corti. The strongest labeling is found in the IHCs (Fig. 7D). ErbB2 labeling is absent from IHC stereociliary bundles and nuclei. Immunoreactivity for erbB2 is found at moderate levels in Deiters' cells, the spiral ligament, and in Claudius' and outer sulcus cells (Fig. 7C). Boettcher's cells are also immunopositive (data not shown). Within the spiral ligament, the marginal region bordering the otic capsule shows strong labeling (Fig. 7C). These cells may correspond to tension fibroblasts or bone-lining cells (Henson and Henson 1988; Chole and Tinling 1994). More moderate erbB2 immunoreactivity is found in the flbrocytes within the spiral ligament. Faint erbB2 immunolabeling is detected in the OHCs (Fig. 7D) and pillar cell heads. Similar to erbB1, the labeling of erbB2 within OHCs has a punctate quality, and the OHC nuclei and stereocilia are unlabeled. Like erbB1, erbB2 labeling is absent from the stria vascularis and basilar membrane (Figs. 7C, D). No significant differences are seen when comparing erbB2 labeling between apical and basal turns of the cochlea. Within the spiral ganglion (Fig. 7F), fewer sensory neuron cell bodies are immunoreactive for erbB2 than erbB1.

Neonatal. Like erbB1, erbB2 labeling is strongest in the cells immediately lateral to the OHCs (Hensen's/ tectal cells) and in the pillar cells (Fig. 6C, D). No erbB2 immunoreactivity is found in hair cells at this age. As was seen with erbB1, faint erbB2 labeling is present in the cells forming the greater epithelial ridge. 


\section{ErbB3}

\section{Vestibular end organs}

Adult. ErbB3 expression was detected in a subset of hair cells in the otolithic (Fig. 8A) and ampullary organs. Supporting cells were unlabeled, as was the transitional epithelium. Satellite cells in the vestibular ganglion are strongly labeled, and many vestibular ganglion neurons are moderately immunopositive (Fig. 8B).

Neonatal. In the vestibular sensory epithelia of P3$\mathrm{P} 5$ mice, erbB3 immunoreactivity is present in the vestibular hair cells and supporting cells (Fig. 5E, F). A small subset of hair cells appears to label more strongly with erbB3 antibodies than adjacent hair cells (not shown).

\section{Organ of Corti}

Adult. In the adult organ of Corti, erbB3 immunoreactivity is seen in both supporting cells and hair cells (Fig. 8D). Outside of the sensory epithelium, Boettcher's cells, outer sulcus cells, and inner sulcus cells also label for erbB3 (data not shown). Moderate erbB3 labeling is detected in the spiral ligament, but it is absent from the stria vascularis (Fig. 8C). Satellite cells in the spiral ganglion are strongly immunopositive for erbB3, whereas the neuron cell bodies are faintly labeled (Fig. 8F).

Neonatal. ErbB3 expression in the neonatal organ of Corti is shown in Figure 6E, F. ErbB3 immunoreactivity is seen in both supporting cells and in sensory hair cells with strong labeling of pillar and Deiters' cells. Cells in the greater epithelial ridge are faintly immunoreactive (Fig. 6E, F), as are the nonsensory cells lateral to the organ (data not shown).

\section{ErbB4}

\section{Vestibular end organs}

Adult. Expression of erbB4 was also examined in the vestibular periphery. In the utricle, saccule, and cristae, type I and II hair cells and supporting cells are immunoreactive (Fig. 9A). ErbB4 is also present in transitional epithelial cells (Fig. 9A). Numerous vestibular ganglion cell bodies are immunoreactive for erbB4 (Fig. 9B). Similar results were obtained using the 0616 and 0618 antisera, although the signal was consistently stronger using 0616.

Neonatal. In P3-P5 vestibular sensory epithelia, erbB4 labeling resembles erbB3 labeling. Both hair cells and support cells are immunoreactive (Fig. $5 \mathrm{G}, \mathrm{H})$.

\section{Organ of Corti}

Adult. ErbB4 antibodies strongly label some organ of Corti cell types, namely in the head and stalk regions of the inner pillar cells (Fig. 9D). Granular
erbB4 staining is also present in neural endings under the OHCs (arrow) and in the IHC region. Occasionally, supporting cells adjacent to the IHCs (e.g., border cells) are strongly labeled in the basal turn of the cochlea (data not shown). Basal cells of the stria vascularis are strongly labeled for erbB4 (Fig. 9C), whereas the spiral limbus is unlabeled (Fig. 9E). As can be seen in Figure 9F, moderate labeling for erbB4 is found in sensory neuron cells bodies within the spiral ganglion.

Neonatal. In the neonatal organ, moderate erbB4 labeling is present in hair cells and supporting cells (Fig. 6G, H). Faint erbB4 immunoreactivity is seen in the cells of the greater epithelial ridge. Moderate labeling is seen in some nonsensory cells lateral to the organ of Corti (Fig. 6G, H).

\section{DISCUSSION}

This study demonstrates the following: (1) There is spontaneous proliferation in cultured neonatal mouse vestibular sensory epithelium, whereas cell division is virtually nonexistent in adult mice; (2) the amount of proliferation in neonatal, but not adult, utricle cultures can be potentiated by heregulin- $\alpha$, an EGF-related ligand; and (3) both neonatal and adult mouse inner ear express receptors for EGF-related ligands (erbBs) (including heregulin- $\alpha$ ) in multiple cell types including support cells. A goal of research in the hair cell regeneration field is to develop therapies to alleviate sensorineural hearing loss and balance disorders resulting from hair cell loss. Our study shows a developmental difference in HRG mitogenicity not directly explained by receptor expression and emphasizes the importance of testing candidate growth factors in adult, as well as neonatal, animals.

\section{Ongoing proliferation differs in neonatal and adult mice}

The amount of proliferation that occurs in the neonatal (P2-P5) mouse utricular macula is orders of magnitude less than that of ongoing proliferation in the vestibular epithelium of birds (Jørgensen and Mathiesen 1988; Weisleder et al. 1995; Kil et al. 1997). Many $(77 \%)$ of the BrdU-labeled cells we describe in cultured mouse utricular maculae are located in pairs or clusters of labeled cells, suggesting that they represent postmitotic pairs. None of the BrdU-labeled SE cells are double-labeled with the hair cell-specific marker calretinin. These data suggest that there are a few new supporting cells produced in the neonatal utricular maculae, but no new hair cells. Our findings are in agreement with the in vivo birthdating studies of Ruben $(1967,1969)$ in developing mouse utricle. 
Ruben reports that new hair cells are added from gestational day 12 (G12) through postnatal day 1 (P1) (not added at P3; P2 not studied), whereas supporting cell production continues a little longer, through P3 (not added at P5; P4 not studied).

In contrast to neonatal stages, virtually no DNA replication occurs in the adult (4-6 week) mouse macula. The numbers of labeled cells in neonatal utricular maculae were significantly different $(P<$ $0.01)$ from those seen in adults. The very rare labeled cell that was seen in adults-one labeled cell in 10 utricular maculae-may be a proliferating leukocyte (Warchol 1997; Bhave et al. 1998; Oesterle et al. 2003).

A small amount of SE cell proliferation has been reported in organotypic cultures of adult guinea pig (Warchol et al. 1993) and mouse utricle (Lambert 1994). The small sample size (4 guinea pig utricles: Warchol et al. 1993; 2 mouse utricles: Lambert 1994) and possible surgical damage to the sensory epithelium makes it difficult to determine whether ongoing SE cell proliferation is present. Three to ten proliferating SE cells per cultured guinea pig utricle were reported by Warchol et al. (1993), but the proliferation appeared at sites of unintentional hair cell lesions that occurred during the surgical removal to culture. Proliferation was not detected in regions of the tissue that contained normal numbers of undamaged hair cells. The two mouse utricle cultures studied by Lambert (1994) contained 1 and 5 labeled SE cells. In organotypic cultures of adult (6-8 week) mice utricles, Yamashita and Oesterle (1995) did not detect significant ongoing proliferation in the utricular macula.

In addition to Ruben's birthdating studies described above, several in vivo studies substantiate the low level of proliferation in the adult utricle. Kuntz and Oesterle (1998a) infused tritiated thymidine into normal adult rats for a 3- or 7-day period, and virtually no normal ongoing proliferation was seen in the utricular macula. Similarly, Li and Forge (1997) and Rubel et al. (1995) infused BrdU or tritiated thymidine into adult guinea pig ears over an extended period and ongoing proliferation was not detected in the utricular macula.

\section{Heregulin- $\alpha$ increases proliferation in neonatal, but not adult, utricular macula}

We find that HRG- $\alpha$ induces a sevenfold increase in proliferation in cultured utricular sensory epithelium of P3-P5 mice. No effect is seen when the utricular sensory epithelia from 4-6-week-old mice are cultured under the same conditions. These results confirm that HRG isoforms are mitogens for vestibular sensory epithelia of neonatal rodents, as was shown previously in rat (Zheng et al. 1999). Other studies have also identified growth factors mitogenic for neonatal inner ear sensory epithelia (e.g., Zheng et al. 1997, 1999; Gu et al. 1998, 1999; Montcouquiol and Corwin 2001). Our studies extend previous findings by showing that HRG does not induce proliferation in the sensory epithelia from mature mice.

The prototype EGF family members, EGF and TGF- $\alpha$, that bind erbB1, have been shown previously to be mitogenic for adult vestibular sensory epithelia (Lambert et al. 1994; Yamashita and Oesterle 1995; Kuntz and Oesterle 1998a). In contrast, preliminary data suggest that the neuregulin GGF-2 is not mitogenic for isolated sheet cultures of $\mathrm{P} 35$ rat utricle (Gu et al. 1997). These data suggest that the mitogenic effects of the neuregulins, in contrast to TGF- $\alpha$, may be limited to developing vestibular sensory epithelia.

In our studies using organotypic cultures of P3-P5 mouse utricle, the maximum (sevenfold) mitogenic effect of $\mathrm{HRG}-\alpha$ was seen at $50 \mathrm{ng} / \mathrm{ml}$. In neonatal rat, the maximum HRG- $\beta$ effect was seen at $30 \mathrm{ng} / \mathrm{ml}$ in utricular epithelial sheet cultures, and a smaller mitogenic effect was seen in organotypic cultures (fivefold increase in SE cell proliferation) (Zheng et al. 1999). The fact that the maximum HRG- $\beta$ effect is found at a lower concentration could either be due to a species difference (mouse vs. rat), a difference in culture techniques (epithelial sheets vs. whole utricle), or a difference between the two HRG isoforms. Heregulin- $\beta$ binds the erbB3 and erbB 4 receptors 100-fold more strongly than HRG- $\alpha$ (Jones et al. 1999). Although the $\beta$-isoform is known to be a more potent mitogen in several tissues, HRG- $\alpha$ is the most potent isoform in mammary epithelium in vivo (Jones et al. 1996). Hence, the effect of the two isoforms is not equivalent and may depend on receptor expression. Heregulin- $\alpha$ is expressed in supporting cells in postnatal rat and adult chinchilla utricular macula (Zheng et al. 1999, Zhang et al. 2002).

In neonatal animals, the magnitude of HRG's mitogenic effects is smaller in organotypic explants (rat: fivefold increase, Zheng et al. 1999; mice: sevenfold increase, our data) than in isolated sheet cultures (rat: tenfold increase, Zheng et al. 1999). The discrepancies between organotypic and sheet cultures may be due to altered erbB expression resulting from the enzymatic and mechanical trauma to the sensory epithelium. Increased FGF receptor and IGF-1 receptor expression have been described in utricular macula sheet cultures relative to that seen in vivo (Zheng et al. 1997). The expression of many other genes is altered by enzymatic treatment and mechanical isolation of the sensory epithelium and this may affect growth factor responsiveness (Chen et al. 2001). In organotypic cultures, the sensory epitheli- 
um maintains its normal contact with the extracellular matrix and more closely resembles the in vivo ear.

The presence of erbB receptors in the $\mathrm{SE}$ and the reports of HRG- $\beta$ 's mitogenic effects in isolated sheet cultures (Zheng et al. 1999) suggest that the mitogenic effect may be a direct effect. However, these sheet culture data must be interpreted cautiously because we show that the transitional epithelium, which borders the sensory epithelium, also expresses erbB receptors. Studies of Montcouquiol and Corwin (2001), using neonatal rat utricular sheet cultures where much of the transitional epithelium was removed, also support the idea that neuregulins can have direct mitogenic effects on the SE.

\section{Supporting cells express erbB receptors}

As described above, in vitro and in vivo studies have shown that the amount of proliferation induced in the vestibular sensory epithelium by members of the EGF family of growth factors (HRG, GGF2, and EGF) differs between adult and neonatal animals. To investigate the possibility that variation in receptor expression for these factors underlies the mammal's limited ability to regenerate hair cells and its developmental regulation of proliferation, we characterized the expression of erbBs (1-4) in both adult and neonatal mouse inner ear by immunohistochemistry (see Tables 3 and 4). This allows a direct correlation of proliferation with expression of the relevant receptors in inner ear sensory epithelium from the same developmental age and species. Although all the major components of the adult inner ear are formed by birth, there is a dramatic postnatal cytological differentiation of the mouse inner ear. We also show that there are significant differences between erbB expression in adult and neonatal mice. In adult mouse vestibular end organs, strong erbB1 labeling is seen in the supporting cells. Interestingly, erbB1 appears to be expressed by all supporting cells in the sensory epithelia. Hence, the limited mitogenic effects seen with TGF- $\alpha$ (a ligand that preferentially activates erbB1 over other erbB dimers) are not the consequence of limited erbB1 expression in a subpopulation of supporting cells but must be the result of additional regulators of proliferation. We show that two additional receptors, erbB2 and erbB4, are also expressed in the vestibular supporting cells of adult mice. ErbB4 labeling is seen throughout the supporting cell cytoplasm, whereas erbB2 labeling is seen predominantly at the apical surface of the sensory epithelium. Like erbB1, erbB2 and erbB4 are expressed in all supporting cells in the vestibular sensory epithelia, not in a subset of cells. Expression of erbBs 1, 2, 4, and possibly erbB3, extends beyond the periphery of the vestibular sensory epithelium into the transitional zone. ErbB1 labeling in the transitional region is consistent with previous findings that TGF- $\alpha$ (Lambert 1994) and TGF- $\alpha$ plus insulin (Kuntz and Oesterle 1998b) induce proliferation in extrasensory regions, including the transitional epithelium.

In the adult cochlea, erbB1, erbB2, and erbB3 are expressed in Deiters' cells, Hensen's cells, and hair cells. ErbB3 is expressed in other organ of Corti supporting cells, including the pillar cells, inner phalangeal cells, and border cells. ErbB4, in contrast, has very limited expression in organ of Corti supporting cells but is expressed in nerve endings innervating the inner and outer hair cells. Extrasensory cells adjacent to the organ of Corti express erbB 1-3 receptors.

Several other groups have analyzed the expression of EGFR and erbBs in the mammalian inner ear. While the majority of studies were conducted in neonatal rats (Malgrange et al. 1998; Staecker et al. 1997; Zine and de Ribaupierre 1999; Zheng et al. 1999; Zine et al. 2000), limited data exist for the adult rat (Saffer et al. 1996; Zheng et al. 1999; Zine et al. 2000; Matsunaga et al. 2001; Daudet et al. 2002) and chinchilla (Zhang et al. 2002). Several of these studies have used RT-PCR techniques that do not provide detailed localization of erbB receptor expression within the labyrinth (Zheng et al. 1999; Saffer et al. 1996). Immunohistochemical techniques were used to characterize erbB expression in adult rat utricle and vestibular ganglion (Zheng et al. 1999; Matsunaga et al. 2001) and erbB1-4 expression in adult chinchilla inner ear (Zhang et al. 2002). The findings in chinchilla and rat appear to be largely consistent with our results in adult mice with several exceptions. In rat, each erbB is present in both the hair cells and supporting cells of the utricular macula (Zheng et al. 1999; Matsunaga et al. 2001). In adult chinchilla, erbBs 2, 3, and 4 are present in the auditory and vestibular sensory epithelia (Zhang et al. 2002). In contrast to mice, erbB2 and erbB3 are also reported to be present in the chinchilla stria vascularis (Zhang et al. 2002). Also, in contrast to our findings in mouse, erbB2 labeling is absent from spiral ganglion cells and minimal in IHCs. It has been suggested that this species difference may implicate erbB2 in the relative protection of mice from the ototoxic effects of carboplatin on the inner ear (Zhang et al. 2002). ErbB signaling involving erbB2 has also been shown to regulate the viability of adult rat vestibular ganglion neurons in vitro (Matsunaga et al. 2001).

Neonatal organ of Corti, like adult organ of Corti, is mitotically quiescent (Ruben 1967; Roberson and Rubel 1994; Sobkowicz et al. 1997; Zine and de Ribaupierre 1998; Zheng et al. 1999) and unable to repair itself after insult via a mitogenic pathway (Sobkowicz et al. 1992, 1996, 1997; Zine and de 
Ribaupierre 1998; Zheng et al. 1999). Exogenous application of EGF, TGF- $\alpha$, or HRG- $\beta 1$ fails to stimulate proliferation in organotypic cultures of neonatal rat organ of Corti (Zine and de Ribaupierre 1998; Zheng et al. 1999). The lack of responsiveness to the EGF family ligands does not appear to be due to an absence of receptors, as each erbB is widely expressed in the organ of Corti. Cells in the greater epithelial ridge also express all erbB receptors (1-4). Others have also analyzed erbB expression in the neonatal rat organ of Corti (Malgrange et al. 1998; Staecker et al. 1997; Zine and de Ribaupierre 1999; Zheng et al. 1999; Zine et al. 2000). As described above, some of these studies utilized PCR or ELISA techniques that do not provide cellular localization within the inner ear (Malgrange et al. 1998; Zine and de Ribaupierre 1999; Zine et al. 2000). In situ hybridization studies of neonatal rat organ of Corti localized erbB1 mRNA to hair cells, supporting cells (Deiters' cells and Hensen's cells), the greater epithelial ridge (Kölliker's organ), and spiral ganglion cells (Zine et al. 2000). Immunohistochemical data from P3 rat organ of Corti suggest the presence of erbB1 in hair cell cytoplasm (Staecker et al. 1997), in stereocilia (Zine and de Ribaupierre 1999), on the surfaces of organ of Corti supporting cells, and at the apical junctions of cells in Kölliker's organ (Zine and de Ribaupierre 1999). Our findings are in agreement with these earlier studies, except that we also see strong erbB1 labeling of cells in the Hensen's/tectal cell region and moderate labeling of cells in the greater epithelial ridge. Unlike the immunofluorescence studies of P3 rat organ of Corti (Zheng et al. 1999), we do not see erbB2 labeling in neonatal mouse hair cells or Deiters' cells. Like rat, we see label in mouse pillar cells and in the greater epithelial ridge.

Neonatal vestibular sensory epithelia, unlike neonatal organ of Corti, do not appear to be mitotically quiescent. As shown in this report, limited proliferation occurs normally in the undamaged neonatal vestibular sensory epithelium. Exogenous EGF family ligands, including EGF, TGF- $\alpha$, GGF2, and HRG, are able to potentiate this proliferation (Zheng et al. 1977; Montcouquiol and Corwin 2001). We detected immunolabeling for all erbBs in supporting cells of neonatal mouse vestibular sensory epithelia. The localization of erbB receptors to the supporting cells is consistent with the mitogenic responsiveness of these cells to the EGF family ligands. Based on experiments using AG825, a specific inhibitor of erbB2, it has been hypothesized that GGF2's proliferative effects are mediated through a receptor complex containing erbB2 (Montcouquiol and Corwin 2001).

Our findings in mice are in agreement with earlier studies in neonatal rat vestibular sensory epithelia (Zheng et al. 1999). PCR techniques were used to detect the presence of erbB2, erbB3, and erbB4 mRNAs in the utricular macula of P3 rats (Zheng et al. 1999). Previous immunofluorescence studies have also shown labeling for erbB2 in P3 rat utricle hair cells, supporting cells, and transitional epithelium (Zheng et al. 1999).

\section{ErbB-deficient mice}

Several groups have generated targeted disruptions of the erbB1-4 genes in an attempt to understand the function of individual erbB receptors (Gassmann et al. 1995; Lee et al. 1995; Miettinen et al. 1995; Sibilia and Wagner 1995; Threadgill et al. 1995; Erickson et al. 1997; Riethmacher et al. 1997; Rio et al. 1997; Sibilia et al. 1998; Morris et al. 1999; Lin et al. 2000). No specific phenotype in the inner ear has been described for any of these strains. Analysis of these mice during embryogenesis and in adults may provide more information about the role of erbBs and their ligands in inner ear development and function.

In summary, we have shown that erbBs 1, 2, 3, and 4 are widely expressed to varying degrees in largely overlapping populations of cells within the neonatal and adult inner ear, including both sensory and nonsensory cell types. The expression of the erbBs in supporting cells, hair cells, and nonsensory cells suggests that they are potentially involved in the regulation of multiple processes, including survival, synaptic maintenance, and cochlear homeostasis, in addition to a role in proliferation. The expression of the receptors for TGF- $\alpha$, EGF, and HRG does not appear to be the limiting factor for regulating proliferation within the sensory epithelium. Further characterization of the downstream signaling components of the erbB pathway may clarify the basis of our inability to induce robust hair cell regeneration in mammals.

\section{ACKNOWLEDGMENTS}

The authors thank Dr. Tama Hasson for her gift of antimyosin VI, Dr. Cary Lai for his gift of anti-erbB4 antibodies, Dr. Nita Maihle for her gift of anti-erbB3 antibody, Sidya Ty for excellent histological work, Glenn MacDonald for assistance with digital photography and imaging techniques, Dr. Jennifer Stone for helpful comments on the manuscript, Dr. Edwin Rubel for use of his laboratory facilities and his enthusiasm, and the anonymous reviewers. Supported by NIH/NIDCD grants DC03944 and DC04661 and the Oticon and American-Scandinavian Foundations.

\section{REFERENCES}

AdLkOFER K, LAI C. Role of neuregulins in glial cell development. Glia 29:104-111, 2000. 
Alroy I, YARDEN Y. The ErbB signaling network in embryogenesis and oncogenesis: signal diversification through combinatorial ligand-receptor interactions. FEBS Lett. 410:83-86, 1997.

Anchan RM, Reh TA, Angello MJ, Balliet A, Walker M. EGF and TGF- $\alpha$ stimulate retinal neuroepithelial cell proliferation in vitro. Neuron 6:923-936, 1991.

Back SY, KIm SU. Proliferation of human Schwann cells induced by neu differentiation factor isoforms. Dev. Neurosci. 20:512-517, 1998.

Bermingham-McDonogh O, McCabe KL, Reh TA. Effects of GGF/ neuregulins on neuronal survival and neurite outgrowth correlate with erbB2/neu expression in developing rat retina. Development 122:1427-1438, 1996.

Bhave SA, Oesterle EC, Coltrera MD. Macrophage and microglialike cells in the avian inner ear. J. Comp. Neurol. 398 (2):241256, 1998.

Burden S, YARden Y. Neuregulins and their receptors: a versatile signaling module in organogenesis and oncogenesis. Neuron 18:847-855, 1997

Carey JP, Fuchs AF, Rubel EW. Hair cell regeneration and recovery of the vestibuloocular reflex in the avian vestibular system. J. Neurophysiol. 76:3301-3312, 1996.

Carraway III KL, Cantley LC. A neu acquaintance for erbB3 and erbB4: a role for receptor heterodimerization in growth signaling. Cell 78:5-8, 1994.

Carraway III KL, Weber JL, Unger MJ, Ledesma J, Yu N, Gassmann C, LAI C. Neuregulin-2, a new ligand of ErbB3/ErbB4-receptor tyrosine kinases. Nature 387:512-516, 1997.

Chang H, Riese II DJ, Gilbert W, Stern DF, McMahan UJ. Ligands for ErbB-family receptors encoded by a neuregulin-like gene. Nature 387:509-512, 1997.

Chen Z, Karimi K, Zhang D, MacDonald R, Corwin JT, Corey DP. The expression landscape of developing utricle: Identification of genes important for inner ear development. Assoc. Res. Otolaryngol. Abs. 24:181, 2001.

Chole RA, Tinling SP. Bone lining cells of the mammalian cochlea. Hear. Res. 75 (1-2):233-243, 1994.

Corwin JT, Cotanche DA. Regeneration of sensory hair cells after acoustic trauma. Science 240:1772-1774, 1988.

Cotanche DA, Lee KH, Stone JS, Picard DA. Hair cell regeneration in the bird cochlea following noise damage or ototoxic drug damage. Anat. Embryol. 189:1-18, 1994.

Cotanche DA. Structural recovery from sound and aminoglycoside damage in the avian cochlea. Audiol. Neurootol. 4 (6):271-285, 1999.

Crovello CS, Lai C, Cantley lC, Carraway III KL. Differential signaling by the epidermal growth factor-like growth factors neuregulin-1 and neuregulin-2. J. Biol. Chem. 273:2695426961, 1998.

Daudet N, Ripoll C, Lenoir M. Transforming Growth Factor-Alphainduced cellular changes in organotypic cultures of juvenile, amikacin-treated rat Organ of Corti. J. Comp. Neurol. 442:6-22, 2002.

Erickson SL, O'Shea KS, Ghaboosi N, Loverro L, Frantz G, BAUer M, Lu LH, Moore MW. ErbB3 is required for normal cerebellar and cardiac development: a comparison with ErbB2- and heregulin-deficient mice. Development 124:49995011, 1997.

Forge A, Li L, Nevill G. Hair cell recovery in the vestibular sensory epithelia of mature guinea pigs. J. Comp. Neurol. 397:69-88, 1998.

Gassmann M, Casagranda F, Orioli D, Simon H, Lai C, Klein R, Lemke G. Aberrant neural and cardiac development in mice lacking the ErbB4 neuregulin receptor. Nature 378:390-394, 1995.

Gu R, Marchionni M, Corwin JT. Age-related decreases in proliferation within isolated mammalian vestibular epithelia cultured in control and Glial Growth Factor 2 media. Assoc. Res. Otolaryngol. Abs. 20:98, 1997.

Gu R, Yang JB, Magal E, Carnahan J. Neu-derived factor enhances supporting cell proliferation in both primary epithelium culture and cell line from rodent vestibular organ. Soc. Neurosci. Abs. 24:556, 1998.

Gu R, Yang JB, Magal E, Carnahan J. Neu-differentiation factor enhances cell proliferation in epithelium culture from rat utricle. Assoc. Res. Otolaryngol. Abs. 22:131, 1999.

Guy PM, Platko JV, Cantley lC, Cerione RA, Carraway III KL. Insect cell-expressed p180 ${ }^{\text {erbB3 }}$ possesses an impaired tyrosine kinase activity. Proc. Natl. Acad. Sci. USA 91:8132-8136, 1994.

Harari D, Tzahar E, Romano J, Shelly M, Pierce JH, Andrews GC, YARDEN Y. Neuregulin-4: a novel growth factor that acts through the ErbB-4 receptor tyrosine kinase. Oncogene 18:2681-2689, 1999.

Hasson T, Gillespie PG, Garcia JA, MacDonald RB, Zhao Y, Yee MS, MoOSEKer MS, Corey DP. Unconventional myosins in innerear sensory epithelia. J. Cell Biol. 137 (6):1287-1307, 1997.

Henson MM, Henson OW. Tension fibroblasts and the connective tissue matrix of the spiral ligament. Hear. Res. 35:237-258, 1988.

Jones FE, Jerry DJ, Guarino BC, Andrews GC, Stern DF. Heregulin induces in vivo proliferation and differentiation of mammary epithelium into secretory lobuloalveoli. Cell Growth Differ 7:1031-1038, 1996.

Jones JT, Akita RW, SLiwkowski MX. Binding specifities of egf domains for ErbB receptors. FEBS 447:227-231, 1999.

Jørgensen JM, Mathiesen C. The avian inner ear. Continuous production of hair cells in vestibular sensory organs, but not in the auditory papilla. Naturwissenschaften 75:319-320, 1988.

Kessel R, Kardon R. Nervous Tissue.Tissues and Organs. W.H. Freeman, San Francisco, pp 106-128, 1979.

KIL J, WARChOL ME, Corwin JT. Cell death, cell proliferation, and estimates of hair cell life spans in the vestibular organs of chicks. Hear. Res. 114:111-126, 1997.

Kuntz AL, Oesterle EC. Transforming growth factor alpha with insulin stimulates cell proliferation in vivo in adult rat vestibular sensory epithelium. J. Comp. Neurol. 399:413-423, 1998a.

Kuntz AL, Oesterle EC. Transforming growth factor- $\alpha$ with insulin induces proliferation in rat utricular extrasensory epithelia. Otolaryngol. Head Neck Surg. 118:816-824, 1998b.

LAMBERT PR. Inner ear hair cell regeneration in a mammal: identification of a triggering factor. Laryngoscope 104:701-718, 1994.

Lee KF, Simon H, Chen H, Bates B, Hung MC, Hauser C. Requirement for neuregulin receptor erbB2 in neural and cardiac development. Nature 378:394-398, 1995.

LEE H, MAIHLE NJ. Isolation and characterization of four alternate c-erbB 3 transcripts expressed in ovarian carcinoma-derived cell lines and normal human tissues. Oncogene 16:3243-3252, 1998.

LemKe G. Neuregulins in development. Mol. Cell Neurosci. 1:241262, 1996.

Li L, Forge A. Morphological evidence for supporting cell to hair cell conversion in the mammalian utricular macula. Int. J. Dev. Neurosci. 15:433-446, 1997.

LILLIEN L. Changes in retinal cell fate induced by overexpression of EGF receptor. Nature 377:158-162, 1995.

Lin W, Sanchez HB, Deerinck T, Morris JK, Ellisman M, Lee K-F. Aberrant development of motor axons and neuromuscular synapses in erbB2-deficient mice. Proc. Natl. Acad. Sci. USA 97:1299-1304, 2000.

Malgrange B, Rogister B, Lefebvre P, Mazy-Servais C, Welcher C, Bonnet C, Hsu R-Y, Rigo J-M, Van de Water TR, Moonen G. Expression of growth factors and their receptors in the postnatal rat cochlea. Neurochem. Res. 23:1133-1138, 1998. 
Marikovsky M, Lavi S, Pinkas-Kramaski R, Karunagaran D, Liu N, WEN D, YARDEN Y. ErbB3-mediated differential mitogenic effects of NDF/heregulin isoforms on mouse keratinocytes. Oncogene 10:1403-1411, 1995.

Matsunaga T, Davis JG, Greene MI. Adult rat otic placode-derived neurons and sensory epithelium express all four erbB receptors: a role in regulating vestibular ganglion neuron viability. DNA Cell Biol. 20 (6):307-319, 2001.

Miettinen PJ, Berger Je, Meneses J, Phung Y, Pedersen RA, Werb Z, DERYNCK R. Epithelial immaturity and multiorgan failure in mice lacking epidermal growth factor receptor. Nature 376:337-341, 1995.

Montcouguiol M, CoRwin JT. Intracellular signals that control cell proliferation in mammalian balance epithelia: key roles for phosphatidylinositol-3 kinase, mammalian target of rapamycin, and $\mathrm{S} 6$ kinases in preference to calcium, protein kinase $\mathrm{C}$, and mitogen-activated protein kinase. J. Neurosci. 21:570-580, 2001.

Morris JK, Lin W, Hauser C, Marchuk Y, Getman D, Lee K-F. Rescue of the cardiac defect in ErbB2 mutant mice reveals essential roles of ErbB2 in peripheral nervous system development. Neuron 23 (2):273-283, 1999.

Oesterle EC, Tsue TT, Rubel EW. Induction of cell proliferation in avian inner ear sensory epithelia by insulin-like growth factor-1 and insulin. J. Comp. Neurol. 380:262-274, 1997.

Oesterle EC, Hume CR. Growth factor regulation of the cell cycle in developing and mature inner ear sensory epithelia. J. Neurocytol. 28:877-887, 1999.

Oesterle EC, Cunningham DE, Westrum LE, Rubel EW. Ultrastructural analysis of $\left[{ }^{3} \mathrm{H}\right]$ thymidine-labelled cells in the rat utricular macula. J. Comp. Neurol. 23:2003 (in press).

Plowman GD, Culouscou JM, Whitney GS, Green JM, Carlton GW, Foy L, Neubauer MG, Shoyab M. Ligand-specific activation of $\mathrm{HER} / \mathrm{p} 180^{\mathrm{erbB} 4}$, a fourth member of the epidermal growth factor receptor family. Proc. Natl. Acad. Sci. USA 90:1746-1750, 1993.

Riese II DJ, Bermingham Y, van RaAj TM, Buckley S, Plowman GD, STERN DF. Betacellulin activates the epidermal growth factor receptor and erbB-4, and induces cellular response patterns distinct from those stimulated by epidermal growth factor or neuregulin-beta. Oncogene 12:345-353, 1996a.

Riese II DL, Kim ED, Elenius K, Buckley S, Klagsbrun M, Plowman DF, STERN DF. The epidermal growth factor receptor couples transforming growth factor-alpha, heparin-binding epidermal growth factor-like factor, and amphiregulin to Neu, ErbB-3, and ErbB-4. J. Biol. Chem. 271:20047-20052, 1996b.

RIESE II DJ, STERn DF. Specificity within the EGF family/ErbB receptor family signaling network. BioEssays 20:41-48, 1998.

Riethmacher D, Sonnenberg-Riethmacher E, Brinkmann V, YamaAi GR, LEwINs GR. Severe neuropathies in mice with targeted mutations in the erbB3 receptor. Nature 389:725-730, 1997.

Rio C, RiefF HI, QI P, Corfas G. Neuregulin and erbB receptors play a critical role in neuronal migration. Neuron 19:39-50, 1997.

Roberson DW, Rubel EW. Cell division in the gerbil cochlea after acoustic trauma. Am. J. Otol. 15 (1):28-34, 1994.

Rubel EW, Dew LA, Roberson DW. Mammalian vestibular hair cell regeneration [letter; comment]. Science 267:701-707, 1995.

Ruben RJ. Development of the inner ear of the mouse: a radioautographic study of terminal mitoses. Acta Otolaryngol. Suppl. 220:1-43, 1967.

Ruben RJ. The synthesis of DNA and RNA in the developing inner ear. Laryngoscope 79:1546-1556, 1969.

Ryals BM, Rubel EW. Hair cell regeneration after acoustic trauma in adult Coturnix quail. Science 240:1774-1776, 1988.

SAFFER LD, Gu R, CoRwin JT. An RT-PCR analysis of mRNA for growth factor receptors in damaged and control sensory epithelia of rat utricles. Hear. Res. 94:14-23, 1996.
Sibilia M, Wagner EF. Strain-dependent epithelial defects in mice lacking the EGF receptor. Science 269:234-238, 1995.

Sibilia M, Steinbach JP, Stingl L, Aguzzi A, Wagner EF. A strainindependent postnatal neurodegeneration in mice lacking the EGF receptor. EMBO J. 17:719-731, 1998.

Sliwkowski MX, Schaefer G, Akita RW, Lofgren JA, Fitzpatrick VD, Nujens A, Fendly BM, Cerione RA, Vandlen RL, Carraway III KL. Coexpression of erbB2 and erbB3 proteins reconstitutes a high affinity receptor for heregulin. J. Biol. Chem. 269:1466114665, 1994.

SMOLDERS JW. Functional recovery in the avian ear after hair cell regeneration. Audiol. Neurootol. 4 (6):286-302, 1999.

Sobkowicz HM, August BK, SLApnick SM. Epithelial repair following mechanical injury of the developing organ of Corti in culture: an electron microscopic and autoradiographic study. Exp. Neural. 115:44-49, 1992.

Sobkowicz HM, August BK, Slapnick SM. Post-traumatic survival and recovery of the auditory sensory cells in culture. Acta Otolaryngol. 116:257-262, 1996.

Sobkowicz HM, August BK, SLAPNick SM. Cellular interactions as a response to injury in the organ of Corti in culture. Int. J. Dev. Neurosci. 15:463-485, 1997.

Staecker H, Dazert S, Malgrange B, Lefebvre PP, Ryan AF, Van de WATER TR. Transforming growth factor alpha treatment alters intracellular calcium levels in hair cells and protects them from ototoxic damage in vitro. Int. J. Dev. Neurosci. 15:553-562, 1997.

STAECKer H, VAN de WATER TR. Factors controlling hair-cell regeneration/repair in the inner ear. Curr. Opin. Neurobiol. 8:480-487, 1998.

Stone JS, Cotanche DA. Identification of the timing of S phase and the patterns of cell proliferation during hair cell regeneration in the chick cochlea. J. Comp. Neurol. 341:50-67, 1994.

Stone JS, Oesterle EC, Rubel EW. Recent insights into regeneration of auditory and vestibular hair cells. Curr. Opin. Neurol. 11:17-24, 1998.

TANYeri H, Lopez I, HonRubia V. Histological evidence for hair cell regeneration after ototoxic cell destruction with local application of gentamicin in the chinchilla crista ampullaris. Hear. Res. 89:194-202, 1995.

Threadgill DW, Dlugosz AA, Hansen LA, Tennenbaum T, Lichti U, Yee D, LaMantia C, Mourton T, Herrup K, Harris RC, et al. Targeted disruption of mouse EGF receptor: effect of genetic background on mutant phenotype. Science 269:230-234, 1995.

Warchol ME, Lambert PR, Goldstein BJ, Forge A, Corwin JT. Regenerative proliferation in inner ear sensory epithelia from adult guinea pigs and humans. Science 259:1619-1622, 1993.

WARCHOL ME, CoRWIN JT. Regenerative proliferation in organ cultures of the avian cochlea: identification of the initial progenitors and determination of the latency of the proliferative response. J. Neurosci. 16 (17):5466-5477, 1996.

WARCHOL ME. Macrophage activity in organ cultures of the avian cochlea: demonstration of a resident population and recruitment to sites of hair cell lesions. J. Neurobiol. 33:724-734, 1997.

Weisleder P, Rubel EW. Hair cell regeneration after streptomycin toxicity in the avian vestibular epithelium. J. Comp. Neurol. 331:97-110, 1993.

Weisleder P, Tsue TT, Rubel EW. Hair cell replacement in avian vestibular epithelium: supporting cell to type I hair cell. Hear. Res. 82 (1):125-133, 1995.

Yamashita H, Oesterle EC. Induction of cell proliferation in mammalian inner-ear sensory epithelia by transforming growth factor alpha and epidermal growth factor. Proc. Nat. Acad. Sci. USA 92:3152-3155, 1995.

Xiang M, Gao WQ, Hasson T, Shin JJ. Requirement for Brn-3c in maturation and survival, but not in fate determination of inner ear hair cells. Development. 125 (20):3935-3946, 1998. 
Zhang D, Sliwkowski MX, Mark M, Frantz G, Akita R, Sun Y, Hillan K, Crowley C, Brush J, Godowski PJ. Neuregulin-3 (NRG3): a novel neural tissue-enriched protein that binds and activates ErbB4. Proc. Natl. Acad. Sci. USA 94:9562-9567, 1997.

Zhang M, Ding D-L, SALvi R. Expression of heregulin and erbB/ HER receptors in the adult chinchilla cochlear and vestibular sensory epithelium. Hear. Res. 169 (1-2):56-68, 2002.

ZHeNG JL, GAO W-Q. Analysis of rat vestibular hair cell development and regeneration using calretinin as an early marker. J. Neurosci. 17:8270-8282, 1997.

Zheng JL, Helbig C, Gao W-Q. Induction of cell proliferation by fibroblast and insulin-like growth factors in pure rat inner ear epithelial cell cultures. J. Neurosci. 17:216-226, 1997.

Zheng JL, Frantz G, Lewis AK, Sliwkowski M, Gao W-Q. Heregulin enhances regenerative proliferation in postnatal rat utricular sensory epithelium after ototoxic damage. J. Neurocytol. 28:901-912, 1999.

Zhu X, Lai C, Thomas S, Burden SJ. Neuregulin receptors, erbB3 and erbB4, are localized at neuromuscular synapses. EMBO J. 14 (23):842-5848, 1995.

Zine A, DE RibaupierRe F. Replacement of mammalian auditory hair cells. Neuroreport 9:263-268, 1998.

Zine A, DE Ribaupierre F. Tissue-specific levels and cellular distribution of epidermal growth factor receptors within control and neomycin-damaged neonatal rat organ of Corti. J. Neurobiol. 38 (3):313-322, 1999.

Zine A, Nyffeler M, DE Ribaupierre F. Spatial expression patterns of epidermal growth factor receptor gene transcripts in the postnatal mammalian cochlea. Hear. Res. 141 (1-2):19-27, 2000. 